\title{
Output Fluctuations and Fiscal Policy: U.S. STATE AND LoCAL GovernMeNTS 1978-1994
}

\author{
Bent E. Sorensen \\ Lisa Wu \\ Oved Yosha
}

Last Revised: DECEMBER 2000

RWP 99-05

\author{
Research Division \\ Federal Reserve Bank of Kansas City
}

Bent E. Sorensen is a senior economist at the Federal Reserve Bank of Kansas City. Lisa Wu is an economist at the Department of Finance Canada. Oved Yosha is a senior lecturer at Tel Aviv University. The authors thank the Armand Hammer Fund for Economic Cooperation in the Middle East, Tel Aviv University, for support, participants at presentations at Brown and Tel Aviv universities and, especially, Robert Inman for helpful comments, Robert Inman and Stephen Mark for access to their estimates of the liabilities of state pension funds, Donna Hirsch at the U.S. Bureau of the Census for help in understanding the data, Phil Barengolts, Shu-Yi Oei, and in particular, David Tom for outstanding research assistance. The views expressed in this paper are not necessarily those of the Federal Reserve Bank of Kansas City, the Federal Reserve System, or the Department of Finance Canada.

Sorensen e-mail: Bent.E.Sorenson@kc.frb.org

Wu e-mail: Wu.Lisa@fin.gc.ca

Yosha e-mail: Yosha@post.tau.ac.il 


\begin{abstract}
What are the cyclical properties of U.S. state and local government fiscal policy? The budget surplus of local and, in particular, state governments is procyclical, smoothing disposable income and consumption of state residents. This happens over both short- and medium-term horizons. Procyclical surpluses are the result of strongly procyclical revenues, and weakly procyclical expenditures. The budgets of trust funds and utilities are procyclical. Federal grants are procyclical, exacerbating the cyclical amplitude of state level income movements; although they smooth the idiosyncratic component of shocks to state output. State and local budget surpluses are affected by balanced budget rules at the short- but not at the medium-term horizon. Further, budgets are less procyclical in conservative states.
\end{abstract} Key words: budget surplus, balanced budget rules, income smoothing JEL Classification: E6, H72 


\section{Introduction}

We investigate the cyclical properties of U.S. state and local government finances. Such an investigation is called for in light of the renewed interest, as illustrated by many recent studies, in fiscal responses to fluctuations in Gross Domestic Product (GDP). For instance, Gavin and Perotti (1997) stress the need for better understanding of fiscal - as opposed to monetary - factors affecting the macroeconomic performance of Latin American countries. [See also Talvi and Vegh (1998).] Sørensen and Yosha (1998) examine the response of the budget surplus to asymmetric fluctuations within the European Union and OECD countries, whereas Lane (1999) studies the cyclical properties of government spending in OECD countries. [See also Goodhart and Smith (1993) and von Hagen and Eichengreen (1996).] From these and other studies, a central stylized fact emerges: while fiscal policy in OECD countries is countercyclical (budget surpluses are higher when GDP rises), it is not so in Latin American countries.

The menu of potential explanations is quite rich. If the persistence in GDP fluctuations differs across countries, we should expect qualitatively different fiscal responses [Gavin and Perotti (1997)]. Borrowing constraints may play a role in some countries, preventing governments from borrowing during "bad times" [Gavin and Perotti (1997)] and fiscal policy may complement market mechanisms for smoothing shocks - an idea consistent with the presence of borrowing constraints at the individual or firm level [Sørensen and Yosha (1998); see also Gali (1994) and Rodrik (1998).] Fiscal policy may also be affected by opportunistic behavior of governments seeking re-election [Rogoff (1990); see Alesina and Roubini (1997) and Drazen (2000) for a comprehensive discussion.] "Keynesian" reverse causality might be at work with fiscal policy affecting GDP fluctuations [Gavin and Perotti (1997)] and, in particular, the volatility of GDP fluctuations [Fatas and Mihov (1999)]. Finally, to explain the special fiscal patterns observed in Latin America - strongly procyclical spending and

\footnotetext{
${ }^{1}$ Barro's (1979) classic tax-smoothing theory is yet another potential explanation for countercyclical fiscal policy. Unfortunately, a central implication of Barro's theory - that tax rates are unpredictable - is rejected in many empirical studies. (The tax-smoothing model is rejected also with the data used here, although we will not report results of such tests.) This does not, however, rule out that tax-smoothing considerations are important.
} 
acyclical surpluses - several economists have suggested that governments reduce budget surpluses during upturns for fear that any accumulated surplus will be spent by others. [See Talvi and Vegh (1998), Stein, Talvi, and Gristani (1999), Lane and Tornell (1998a, 1998b), and Tornell and Lane (1999).] Lane and Tornell refer to this phenomenon as the "voracity effect."

We perform a comprehensive panel data analysis of these issues for U.S. state and local governments. The budgets of these governments are large relative to U.S. GDP and it is important to understand their behavior. Since institutional structures vary across states we can exploit this variation in order to uncover determinants of fiscal behavior. We do not adopt a structural approach, but draw on the existing menu of models for interpretation.

Previous empirical work on the topic includes Gramlich (1991), Poterba (1994), and Eichengreen and Bayoumi (1994). ${ }^{2}$ We devote subsection 3.5 to a comparison of our work to the results and methodology in these papers. One contribution of our study is that it uses state-level panel data for a reasonably long period of time and addresses the various issues in a unified framework. In addition, it addresses several issues that have not been studied before. Most of the analysis is carried out using univariate regression specifications. Obviously, such a framework does not fully capture the dynamic patterns in the data, and we, therefore, study more elaborate dynamic specifications in subsection 3.3. The results indicate that the main qualitative conclusions from the univariate regressions hold up, but yield interesting new insights regarding the temporal response of various fiscal components to output fluctuations. ${ }^{3}$

In many instances, local government finances are dictated by state governments through legislation and grants. The latter may off-load fiscal burdens to local governments in order to balance the state budget, or may be pressured to help local governments in bad times. ${ }^{4}$ For example, some states - notably Michigan, South Dakota, and Wisconsin-increased

\footnotetext{
${ }^{2}$ See also Alesina and Bayoumi (1996), Bohn and Inman (1996), and Inman and Mark (1998).

${ }^{3}$ We thank Valerie Ramey for encouraging us to pursue the dynamic analysis.

${ }^{4}$ In fact, the "division of labor" between state governments and local governments is constantly changing. Over the past few years, there have been many shifts in state versus local government responsibilities with large variation among states: a few states have taken over responsibility for local courts, some have implemented welfare reform by shifting more responsibility to local governments, and most states have been shifting mental health patients from state institutions to local community programs.
} 
state taxes in recent years because they were concentrating on reducing local property taxes. ${ }^{5}$ We, therefore, also study the finances of local governments and compare their cyclical properties to those of state governments.

As stressed by Gavin and Perotti (1997), it is of great interest to study the finances of non-financial public enterprises separately since such entities often play an important role in overall fiscal performance. In the United States, state and local governments control insurance trust funds, utilities, and liquor stores. Their operations are less conspicuous than other activities (being "off-budget"), so state and local governments may be tempted to shift deficits to these entities. ${ }^{6}$ We, therefore, also study - to our knowledge for the first time - the cyclical patterns in the finances of trust funds (mainly unemployment and pension funds), utilities, and liquor stores.

It is also important to examine which budget components dominate the cyclical behavior of budget surpluses. ${ }^{7}$ We study the behavior of three such components over the cycle: intergovernmental grants, other revenue, and expenditure. We make no assumption as to whether taxes or expenditure are exogenous and do not attempt to separate tax-smoothing motives from other motives for cyclical fiscal policy; nor do we attempt to separate predictable from non-predictable shocks to output. We do, however, distinguish between state-specific and U.S.-wide output fluctuations - a distinction which yields interesting findings. ${ }^{8}$

Unlike country-level governments, virtually all U.S. states have adopted balanced-budget restrictions. ${ }^{9}$ The stringency of these restrictions varies across U.S. states which has helped

\footnotetext{
${ }^{5}$ See State Policy Reports (1998), Vol. 16.

${ }^{6}$ Of related interest is Inman and Mark's (1998) study of the determinants of underfunding of U.S. state-level public employee pension plans and Auerbach's (1994) argument that mechanisms designed for deficit reduction failed at the U.S. national level due to "budget gimmicks" and intertemporal reallocation of expenditure items. For a picturesque exposition of this line of argument, see Bennett and DiLorenzo (1983).

${ }^{7}$ Lane (1999), for example, focuses entirely on government spending (rather than on the budget surplus) in OECD countries.

${ }^{8}$ Of course, cyclical fiscal policy may be an unintended result of institutional rigidities in tax-collecting and budgeting (although tax collection and budgeting practices would eventually be changed if such rigidities caused major departures from the desired consumption path). We address this issue in our empirical work.

${ }^{9}$ The closest institutions to balanced-budget rules at the country level are the 1992 Maastricht Treaty requirements that were adopted by European countries prior to Monetary Unification. See Poterba and von Hagen (1999) who stress the importance of assessing how effective such institutions are in shaping fiscal
} 
researchers explore if such rules are effective in reducing fiscal deficits. ${ }^{10}$ We examine the effect of the stringency of these rules on the cyclical patterns of fiscal policy (as others have done), and test the conjecture that more stringent balanced budget restrictions create stronger incentives for off-budgeting. We further investigate the effect of historical debt levels on the procyclicality of budget surpluses and whether low historical debt levels simply proxy for tight balanced budget restrictions.

We then briefly explore institutional and political economy issues. For example, we look at whether reliance on certain types of taxes (e.g., income taxes versus indirect taxes) or the occurrence of state gubernatorial elections affect the cyclical behavior of the surplus. A central result is that state governments refrain from accumulating larger surpluses in "good years" that also happen to be election years. No such asymmetry (between election and non-election years) is apparent in "bad years."

We conclude the empirical analysis with a comparison to estimates reported in Asdrubali, Sørensen, and Yosha (1996) regarding the amount of income and consumption smoothing achieved among U.S. states through various mechanisms. Using the method developed in that paper, we find that state and local governments smooth on average 3.7 percent of state-specific output fluctuations. This is not a negligible number, but it is small in comparison to the estimates for national OECD governments reported in Sørensen and Yosha (1998).

In the next section we describe the sample. In sections 3 to 7 we present the empirical analysis and the empirical results, including a detailed comparison with earlier work. Section 8 concludes the paper.

\footnotetext{
policy.

${ }^{10}$ See Eichengreen and Bayoumi (1994), Poterba (1994), Alesina and Bayoumi (1996), and Bohn and Inman (1996).
} 


\section{Data}

The data are from Governmental Finances, U.S. Bureau of the Census, covering the period 1978-1994. ${ }^{11}$ We were not able to obtain data for some of our series prior to 1978 . We refer to utilities, insurance trust funds, and liquor stores as UILs. Our sample includes the 48 mainland states. ${ }^{12}$ Table 1 displays the average per capita real surplus, revenue, and expenditure of state and local governments and the surplus of UILs for our sample period. ${ }^{13}$ In the rows labeled std1 and std2, we show, for each variable, the cross-state standard deviation (averaged over the years of the subperiod) and the time-series standard deviation (averaged across states).

Table 1 about here.

To further illustrate the order of magnitude of state and local budget items, we note that in 1994, for example, total (general + UILs) per capita revenue and expenditure of state governments were each on the order of 12-13 percent of per capita gross state product (GSP), with the total surplus (including UILs) amounting to approximately 1 percent of GSP. ${ }^{14}$

The 1994 revenue of state insurance trust funds was about 2 percent of GSP whereas the revenue of local insurance trust funds as a fraction of GSP was negligible. In the same year, the budget size of state-managed utilities was very small as a fraction of GSP, while the expenditure of local government managed utilities was about 1 percent of GSP.

Table 2 about here.

\footnotetext{
${ }^{11}$ We also benefited from estimates of the liabilities of state pension funds kindly provided to us by Robert Inman and Stephen Mark. We present further details regarding these estimates later.

${ }^{12}$ Alaska relies heavily on severance taxes and exhibits a huge variation in several fiscal components as a result of variability in oil prices. Hawaii has a very particular institutional structure.

${ }^{13}$ In Governmental Finances, the accounts of utilities, liquor stores, and insurance trust activities are displayed separately.

${ }^{14} \mathrm{GSP}$ is the state-level counterpart of country-level GDP. General revenue and expenditure refer to all the revenue and expenditure of a state government which are quite different from the revenue and expenditure associated with the more restricted "general fund."
} 
Table 2 displays intergovernmental per capita net transfers across various levels of government. In 1994, these transfers constituted roughly 3.1, 0.3, and 2.9 percent of GSP.

\section{Cyclical Properties of Fiscal Policy}

\subsection{Budget surpluses}

We first want to determine whether U.S. state and local governments exhibit procyclical budget surpluses, as do OECD country-level governments, or acyclical surpluses, as in Latin America. To capture this empirically in a simple manner, we estimate the following model:

$$
\mathrm{S}_{i t}=\alpha_{i S}+\gamma_{t S}+\beta_{\mathrm{S}} \Delta \mathrm{GSP}_{i t}+\epsilon_{i t S} .
$$

The $\alpha_{i S}$ variables are "state-fixed effects" (dummy variables for each state) that control for any cross-sectional variation that is constant over the sample period, such as the relative size of state $i$. The "time-fixed effects" (time dummies), $\gamma_{t S}$, control for any aggregate timeseries variation, including macroeconomic variables such as U.S.-wide GDP or monetary policy. The coefficient $\beta_{\mathrm{S}}$ is interpreted as the response of the surplus to an idiosyncratic (state-specific) change in GSP. The advantage of this simple specification is that the coefficients are easily interpretable and coefficients estimated for various budgets and budget components can be easily compared since they represent dollar-to-dollar responses. For better exposition, we multiply the estimated coefficient by 100, so that the displayed coefficient is interpreted as the response of the budget surplus to a 100 dollar change in output. We run all the regressions with and without time-fixed effects. Since the budget surplus (i.e., state and local government saving) is stationary while GSP is not, we regress the per capita budget surplus on the first difference of GSP. ${ }^{15}$ We correct for autocorrelation in the

\footnotetext{
${ }^{15}$ We performed Dickey-Fuller tests for unit roots in the GSP and budget surplus series. The tests easily reject unit roots in the budget surplus, but never reject unit roots in GSP. Since the tests have low power due to the relatively short data series, we also based our judgment on visual inspection of the series. Since aggregate (longer) time-series of output behave like unit root or near unit root processes, we used the GSP series in first-differenced form in order to avoid potentially spurious inferences.
} 
residuals using a standard two-step Prais-Winsten procedure, and for heteroskedasticity using a two-step procedure which allows for different error variances across states.

In the various tables, we display the results of two types of regressions. The numbers in columns with the heading $k=1$ are obtained by regressing the current budget surplus on 1-year differenced GSP. The numbers displayed in columns with the heading $k=3$ are obtained by regressing the total budget surplus over 3 years, $s_{i t}+s_{i, t-1}+s_{i, t-2}$, on 3 -year differenced GSP, GSP $i t-$ GSP $_{i, t-3}$, using non-overlapping data. The interpretation of the coefficient in the latter regression is the net 3-year response of the budget surplus, in dollars, to a 100 dollar increase in GSP. Comparing the estimated coefficient from a 3-year regression with the coefficient from a 1-year regression gives us a sense of the dynamic response of budget surpluses to GSP fluctuations. For example, a 3-year response that is much larger than a 1-year response indicates that surpluses revert to zero very slowly after output shocks.

Table 3 about here.

Table 3 displays the cyclical properties of state and local total (including UILs) budget surpluses, with and without time-fixed effects. From the estimated coefficients of the regressions without time-fixed effects, we learn that the surpluses of state and local governments are strongly and significantly procyclical, especially at the 3-year frequency. Interpreting the magnitude of the coefficients, if the change in per capita state output over a 3-year period is 100 dollars, the cumulative (over 3 years) per capita state and local government surpluses increase by 8.62 and 2.57 dollars, respectively. The results with time-fixed effects are similar and suggest that state and local governments do not respond differently to idiosyncratic and aggregate output shocks.

\section{$3.2 \quad$ Budget components}

Next, we want to determine which budget components are responsible for the procyclicality of state and local government budget surpluses. The year $t$ budget surplus of state $i$ 's 
government can be broken down as follows,

$$
\mathrm{S}_{i t}=\operatorname{GRANTS}_{i t}+\mathrm{OWNREV}_{i t}-\mathrm{EXP}_{i t},
$$

where GRANTS are federal grants, ${ }^{16}$ OWNREV is the revenue of the state government raised within state (total tax revenue, including fees, excluding federal grants), and EXP is the total expenditure of the state government. An analogous breakdown holds for local governments with GRANTS representing federal grants plus state government grants. Intergovernmental grants are studied here since they are part of the state and local government budgets and potentially affect the cyclical behavior of deficits and surpluses.

While state government budget surpluses behave like stationary time series, the components of the surplus in equation (2) behave like unit root processes. ${ }^{17} \mathrm{We}$, therefore, analyze the comovement of the first difference of each component with the first difference of GSP by estimating the following models:

$$
\begin{gathered}
\Delta \operatorname{GRANTS}_{i t}=\alpha_{i \mathrm{G}}+\gamma_{t \mathrm{G}}+\beta_{\mathrm{G}} \Delta \mathrm{GSP}_{i t}+\epsilon_{i t \mathrm{G}}, \\
\Delta \mathrm{OWNREV}_{i t}=\alpha_{i \mathrm{R}}+\gamma_{t \mathrm{R}}+\beta_{\mathrm{R}} \Delta \mathrm{GSP}_{i t}+\epsilon_{i t \mathrm{R}} \\
\Delta \operatorname{EXP}_{i t}=\alpha_{i \mathrm{E}}+\gamma_{t \mathrm{E}}+\beta_{\mathrm{E}} \Delta \mathrm{GSP}_{i t}+\epsilon_{i t \mathrm{E}} .
\end{gathered}
$$

We estimate the models with and without time-fixed effects.

Table 4 about here.

Table 4 displays the regression coefficients (multiplied by 100). ${ }^{18}$ It is readily apparent

\footnotetext{
${ }^{16}$ More precisely, we use net federal grants calculated as state government revenue from the federal government minus federal revenue from the state government.

${ }^{17}$ This, of course, implies that we regard grants, revenue, and expenditure as cointegrated. The timedimension of our sample is too short for formal tests to have reasonable power so we do not report DickeyFuller and cointegration tests. We return to this issue in subsection 3.3.

${ }^{18}$ The reported numbers for the three budget components do not exactly add up to the numbers reported in Table 3 since the left-hand variables in the regressions of Table 4 are first-differenced while the left-hand side variable (the budget surplus) in the regressions of Table 3 is not.
} 
from the two panels that state government revenue raised within state is strongly procyclical; namely, revenue is higher during upturns. This is not surprising since many taxes are proportional to income and the personal income tax is typically progressive. Later, we explore this issue in more detail by checking whether the procyclicality of the surplus varies systematically between states with different tax structures. ${ }^{19}$

State expenditure is also procyclical, but the procyclicality of revenue dominates so that budget surpluses are procyclical as reported in the previous subsection.

We turn to federal grants. When time-fixed effects are not included, these grants are positively correlated with GSP fluctuations, increasing the resources available to state governments in good times and decreasing them in bad times (other things being equal, of course). Since many grants are "progressive," in the sense that they are directly tied to the level of poverty within a state (Medicaid, in particular), an opposite result might have been expected. When we control for U.S.-wide effects by including time-fixed effects - see the lower panel of Table 4 -we find that federal grants indeed possess insurance properties: they are negatively correlated with idiosyncratic GSP fluctuations, and are higher in statespecific slumps. ${ }^{20}$ The effect is rather small, since federal grants typically constitute no more than 25 percent of total state government revenue. Our interpretation of these results is that federal grants do provide some insurance against state-specific downturns and that, in addition, federal grants are more generous during U.S.-wide upturns.

In Table 5 we display the cyclical properties of the components of local government budget surpluses: federal grants, state government grants, own revenue, and expenditure. The results are overall similar to those for state governments. When time-fixed effects are not included, federal and state grants are positively correlated with output, but when we

\footnotetext{
${ }^{19}$ Valerie Ramey, in her discussion of this paper, suggested the following exercise: plot the GSP and state government revenue of New Hampshire (where there is no income tax) and California (where the income tax is highly progressive). As one might expect, revenue tracks GSP more closely in California than in New Hampshire. Our empirical analysis in Section 6 confirms this intuition.

${ }^{20}$ Since federal grants are a source of revenue not raised from the residents of the state, an increase in grants received, for a given expenditure and budget surplus, allows the state government to tax the residents of the state by a smaller amount. Thus, federal grants smooth income in a state if they vary negatively with gross state output (that is, if $\beta_{\mathrm{G}}<0$ ). Our findings here are in line with studies documenting the federally-provided income insurance to state output through the federal tax-transfer system; see, e.g., Salai-Martin and Sachs (1992), von Hagen (1992), Asdrubali, Sørensen, and Yosha (1996), and Sørensen and Yosha (1999).
} 
control for U.S.-wide fluctuations by including time-fixed effects - see the lower panel of Table 5-we find that federal grants to local governments are slightly (although not significantly) countercyclical.

Table 5 about here.

Looking at the top panel of Table 5, where time-fixed effects are not included, we find that the own revenue of local governments is procyclical, but to a much smaller extent than state government revenue, probably because local government taxes are less directly tied to income. Local government expenditure is also procyclical and the regression coefficients are of the same order of magnitude as those for state government expenditure.

In the bottom panel, with time-fixed effects, we see that at the 3-year horizon, federal government grants to local governments do not exhibit significant cyclical patterns, although we still see significant procyclical movements in state government grants to local governments. Local government revenue and expenditure do not vary significantly with output at the 1-year frequency, but both components are procyclical at the 3 -year frequency. ${ }^{21}$

We do not find it attractive to regress the growth rate of the surplus on GSP growth, since the surplus hovers around zero; but for expenditure and revenue components one might prefer regressions in log-differences. We experimented with such regressions and found results qualitatively similar to those reported for level regressions. ${ }^{22}$

\subsection{A more explicit dynamic analysis}

The empirical analysis so far captures dynamic effects through the length of the differencing interval (1 or 3 years). In order to examine if this approach misses any salient features of the data, this subsection presents the results of explicit dynamic regressions. To ascertain

\footnotetext{
${ }^{21}$ We further studied the response of state and local government fiscal policy to positive and negative output shocks, and did not find much evidence of asymmetric fiscal responses to such shocks. This is unlike the findings for national governments reported in Gavin and Perotti (1997).

${ }^{22}$ No coefficients changed sign or statistical significance. The magnitude of the estimated coefficients changed, of course, as the coefficients in " $\Delta$-log" regressions are interpreted as elasticities. The only fact revealed by such regressions, not observable from our tables, is that grants have a slightly higher elasticity with respect to GSP fluctuations than own revenue.
} 
that the results are not driven by the way we difference the data, we start out by estimating the following dynamic relations in levels, for state governments: ${ }^{23}$

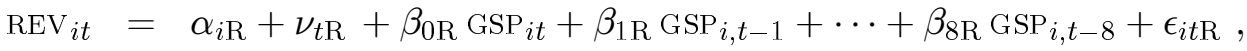

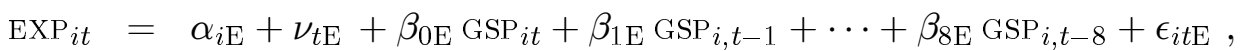

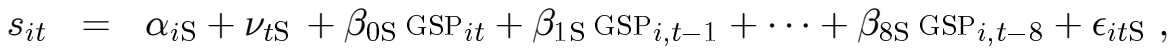

using 8 lags, where REv $i t$ is total revenue $\left(\right.$ OWNREV $\left._{i t}+\operatorname{GRANTS}_{i t}\right), \operatorname{EXP}_{i t}$ is total expenditure, and $\mathrm{s}_{i t}$ is total surplus. ${ }^{24}$

The variables in these regressions, except the surplus, are non-stationary so the estimated t-statistics do not follow standard t-distributions and we do not tabulate the parameter estimates. The results are, nevertheless, simple to interpret from a graph displaying the predicted response of the fiscal variables to a one-time permanent increase in GSP. (See Fig. 1.) The following patterns are clearly visible: (1) both revenue and expenditure respond positively over several periods; (2) revenue responds immediately and more sharply while expenditure responds more gradually; (3) this results in a positive response of the surplus; (4) after 3 to 4 years, expenditure catches up with revenue so that the positive effect on the surplus vanishes. ${ }^{25}$

Fig. 1 about here.

\footnotetext{
${ }^{23}$ The results for the consolidated budgets of state and local governments are very similar.

${ }^{24}$ The overall results are not sensitive to the exact number of lags used.

${ }^{25}$ The results are not very sensitive to the specification of the dynamic model. We experimented with a bivariate specification where a second equation allowed for lagged output and surplus to feed back into GSP. Parameter estimates from such a standard Vector Auto-Regressive (VAR) model, with the identifying assumption that current GSP is exogenous to current state government surplus, imply an impulse response function for the surplus that is very similar to the graph for the impact of a permanent GSP shock displayed in Fig. 1. This is due to the impact of GSP shocks on the surplus being rather small relative to the size of GSP, and although our point estimates imply positive feed-back effects from lagged surplus to GSP, these effects are too small to change the overall picture. Furthermore, in a VAR model, one traces the impact of an innovation to GSP rather than a one-time permanent increase; but since GSP is so close to a random walk, the difference is minor. (Our point estimates indicate that, typically, a 100 dollar shock to GSP will grow to a 110 dollar increase after a year but will settle down to an increase of about 90 dollars after several years.) We chose not to display the results of a standard VAR model for two reasons: first, we prefer to maintain the assumption that GSP is exogenous to be consistent with the analysis in other sections of the paper; and second, including lagged fiscal variables results in the loss of a full year's worth of observations for every lag included which is not attractive given our short sample.
} 
It is clearly visible from Fig. 1 that revenue and expenditure are not stationary processes (assuming that GSP is not stationary), since the impact of a permanent GSP shock does not diminish over time. By contrast, the surplus is clearly mean reverting. Since the surplus is revenue minus expenditure, this implies that revenue and expenditure are cointegrated processes, with the latter "catching up" with the former in finite time (approximately 3 to 4 years). Paraphrasing a well-known saying, Fig. 1 is "worth more than a thousand cointegration tests."

Do the qualitative implications of our results depend on whether the data are differenced or not? To address this issue, we estimate similar regressions using stationary variables:

$$
\begin{aligned}
\Delta \mathrm{REV}_{i t} & =\alpha_{i \mathrm{R}}\left(+\nu_{t \mathrm{R}}\right)+\beta_{0 \mathrm{R}} \Delta \mathrm{GSP}_{i t}+\beta_{1 \mathrm{R}} \Delta \mathrm{GSP}_{i, t-1}+\cdots+\beta_{5 \mathrm{R}} \Delta \mathrm{GSP}_{i, t-1}+\epsilon_{i t \mathrm{R}} \\
\Delta \mathrm{EXP}_{i t} & =\alpha_{i \mathrm{E}}\left(+\nu_{t \mathrm{E}}\right)+\beta_{0 \mathrm{E}} \Delta \mathrm{GSP}_{i t}+\beta_{1 \mathrm{E}} \Delta \mathrm{GSP}_{i, t-1}+\cdots+\beta_{5 \mathrm{E}} \Delta \mathrm{GSP}_{i, t-1}+\epsilon_{i t \mathrm{E}} \\
s_{i t} & =\alpha_{i \mathrm{~S}}\left(+\nu_{t \mathrm{~S}}\right)+\beta_{0 \mathrm{~S}} \Delta \mathrm{GSP}_{i t}+\beta_{1 \mathrm{~S}} \Delta \mathrm{GSP}_{i, t-1}+\cdots+\beta_{5 \mathrm{~S}} \Delta \mathrm{GSP}_{i, t-1}+\epsilon_{i t \mathrm{~S}}
\end{aligned}
$$

The results, with and without time-fixed effects, are displayed in Table $6 .{ }^{26}$ The results in these regressions are comparable to those in equations (1), (4), and (5). ${ }^{27}$

Table 6 about here.

The time-fixed effects are potentially important since they control for all nation-wide effects, including federal government fiscal policy and monetary policy as well as changes in federal legislation and adjustment in federal grants to states. The results in Table 6 show a clear pattern that does not depend on whether time-fixed effects are included or not, and resembles the patterns obtained from regressions in levels (Fig. 1). Revenue reacts instantly (and positively) to a positive GSP shock and continues to increase substantially in the first

\footnotetext{
${ }^{26}$ In these regressions too, the results for the consolidated budgets of state and local governments are similar. The results are also invariant to the exact number of lags used.

${ }^{27}$ The revenue variables differ somewhat (in equation (4) federal grants are not included), but for brevity we do not present more detailed regressions since the main patterns in the data are not very sensitive to these details.
} 
and second years after the shock. Expenditure also reacts positively to a positive GSP shock, but much slower than revenue. In both regressions, with and without time-fixed effects, the largest increase in expenditure occurs in the second year after the shock. There seems to be a small further increase in subsequent years but this effect is not very robust. (For instance, in the regression without time-fixed effects, the coefficient of 3-year lagged GSP is negative.) The surplus rises substantially in the first years after a positive GSP shock and then declines, reaching zero after 3 to 5 years.

Revenue and expenditure react more strongly to GSP shocks when time-fixed effects are not included. This means that the fiscal response of a single state is stronger to nation-wide than to state-specific shocks. This may reflect some kind of herd behavior, or a common response to changes in federal government legislation (e.g., the federal government changes the "rules of the game" in response to a U.S.-wide GDP shock and all state governments respond in a similar manner). Alternatively - on the revenue side - the stronger response to GSP shocks when time-fixed effects are not included may reflect changes in federal grants policy.

The empirical results in this subsection are consistent with those reported above, using 1-year versus 3-year differencing. There, at the 1-year frequency, we saw a strong positive response of revenue and a weaker response of expenditure to a positive GSP shock, whereas at the 3-year frequency the response of revenue less than doubles while that of expenditure triples (Table 4). The 1-year versus 3-year analysis captures the increase of the surplus in each of the first years following a positive GSP shock well, but it does not capture the subsequent reversion to the mean. Nevertheless, in the remainder of the paper we will concentrate on the simpler specification with 1-year and 3-year differencing. This specification captures the essential dynamics in the data reasonably well and is substantially more parameter parsimonious.

\subsection{Interpretation}

The procyclicality of state and local government expenditure is consistent with the findings

of Gavin and Perotti (1997), Talvi and Vegh (1998), and Lane (1999) for country-level 
governments. ${ }^{28}$ A possible explanation is that government consumption behaves according to the "Permanent Income Hypothesis" with government consumption responding positively to persistent positive output shocks. A second explanation is that the federal government, or the courts, impose higher expenditure on state governments in business cycle upturns (e.g., more generous health care benefits or better schooling services that the state or local governments must provide). The recent tax increases in many states due to state court orders to equalize school finance are a pertinent example. ${ }^{29}$ A third potential explanation is that the procyclicality of expenditure is driven mainly by capital expenditure since some parts of such expenditure are better regarded as investment than as consumption: for example, necessary spending on the maintenance of highway and school structures. In the next section we demonstrate that capital spending indeed is procyclical, but that it is not the main underlying source of procyclical state government expenditure.

Procyclical expenditure is also consistent with voracity: during upturns, governments spend more for fear that any accumulated surplus will be spent by others. Talvi and Vegh (1998) argue that such behavior is more likely the more volatile the tax base. Statelevel gross product is considerably more volatile than U.S. GDP, which is in line with the Talvi-Vegh interpretation but, nevertheless, we find this hypothesis less appealing since U.S. state and local government revenue and surpluses are highly procyclical, while state government expenditure is much less so, a pattern that does not provide strong support for a voracity effect. ${ }^{30}$

A potential interpretation of the procyclicality of surpluses is that state and local governments use the budget to smooth the disposable income of state residents. This might be optimal if some consumers are not able to diversify income sources on nation-wide or in-

\footnotetext{
${ }^{28}$ Talvi and Vegh (1998) argue that government expenditure in the G-7 countries is acyclical, and is procyclical only for developing countries. This observation is based on simple correlations (not regression analysis) which may be the cause of this (minor) difference in results.

${ }^{29}$ State Budget \& Tax News, April 3, 1998.

${ }^{30}$ Following the suggestion of a referee we split the sample of U.S. states according to the variability of GSP and according to the "asymmetry" of output fluctuations using a measure calculated in Kalemli-Ozcan, Sørensen, and Yosha (2000). (Roughly, output fluctuations of a state are asymmetric if they have a low correlation with aggregate fluctuations and if they are more variable than aggregate fluctuations.) We did not, however, see any difference in budget cyclicality across those groupings for state governments. (For local governments, we found minor-but hard to interpret-differences.)
} 
ternational capital markets or are unable to smooth consumption due to credit constraints. Such an interpretation corresponds well with the findings in Sørensen and Yosha (1998) regarding the consumption smoothing role of OECD national-level governments (especially over longer horizons). ${ }^{31}$ We return to this issue in Section 7.

Turning to the fiscal behavior of local governments, the results in Table 5 indicate that local government budgets move together with those of state governments. This may be because local governments face the same environment as state governments or, perhaps, because state governments off-load part of the fiscal burden to local governments. We will return to this issue.

\subsection{Comparison with results in the literature}

This is a good junction to pause and check whether our results fit with what is already known on this topic, and whether some of the empirical regularities can indeed be regarded as stylized facts. We begin with Eichengreen and Bayoumi (1994) who regress the surplus/GSP ratio on the growth rate of GSP and on the one period lagged surplus/GSP ratio, using year-by-year observations for the period 1971-90. A positive coefficient on the growth rate of GSP is interpreted as "stabilizing fiscal policy." The numerical value of the coefficient cannot be compared to our coefficient (which measures the dollar response of the surplus to a dollar change in output) but qualitatively, a positive coefficient indicates that the budget surplus grows more than proportionately than output in years with high output growth. Eichengreen and Bayoumi obtain a positive and significant coefficient for state governments, which is fully consistent with our results, but an insignificant coefficient for local governments which appears at first sight inconsistent with our results. The results of Eichengreen and Bayoumi can be thought of as measuring the amount of "income stabilization" provided through the budget, since their regressions measure how government saving, measured as a fraction of GSP, varies over the cycle. These results are more comparable to (and agree with) our results for income smoothing reported in Section $7 .{ }^{32}$

\footnotetext{
${ }^{31}$ See also Arreaza, Sørensen, and Yosha (1999).

${ }^{32}$ Those results confirm that local government surpluses provide very little income insurance.
} 
Gramlich (1991) uses annual aggregate (US-wide) data on state and local government budgets for the period 1955-90. He regresses the ratio "spending/GNP" and the ratio "taxes/GNP" on the lagged stock of debt, federal grants, other grants, a price deflator for state and local government purchases, the health cost price deflator, and the current and lagged unemployment rate. ${ }^{33}$ He finds that spending is affected positively by the US-wide unemployment rate whereas we found that spending is affected positively when GSP rises. These results do not point in the same direction, but need not be regarded as contradicting since there is no year-by-year correspondence between GSP changes and the unemployment rate. Gramlich further finds that taxes are affected negatively by the lagged unemployment rate. This is fully consistent with our finding of higher tax revenue when GSP is high. ${ }^{34}$

Poterba (1994) is concerned with the fiscal response of state governments to fiscal surprises (fiscal shocks). He cleverly exploits a yearly survey by the National Association of State Budget Officers (NASBO) that reports information about actual revenue and expenditure in the previous fiscal year, current fiscal year revenue and expenditure as projected at the beginning of the year, and any "planned" spending or tax changes that have been enacted during the current year. ${ }^{35}$

Poterba regresses the "planned" change in taxes and in spending of state governments on the fiscal shocks. (The "planned" changes in taxes and spending are regarded as the response of state governments to fiscal shocks.) He finds a negative response of "planned" expenditure changes to deficit shocks (expenditure increases in good years and decreases in bad years) and a positive response of "planned" tax changes to deficit shocks (taxes decrease in good years and increase in bad years). If we draw an analogy between a positive fiscal shock and a rise in GSP, we can say that Poterba's finding regarding expenditure is

\footnotetext{
${ }^{33}$ The independent budgetary variables are also divided by GNP, and the price deflators are divided by the GNP deflator.

${ }^{34}$ Gramlich does not report results regarding the response of state and local government budget surpluses to the national unemployment rate, nor does he disentangle state government and local government budgets.

${ }^{35}$ Poterba (1994) defines a revenue shock as "(actual revenue - "planned" tax change) - forecast revenue" and an expenditure shock as "(actual outlays - "planned" spending change) - forecast outlays." The magnitude "(actual revenue - "planned" tax change)" measures the revenue that would have been collected absent the change in taxes, namely, prior to the response to the shock. Therefore, to obtain an estimate of the shock, forecast revenue should be subtracted from this magnitude (not from actual revenue). In a similar fashion, estimates for spending shocks are obtained. A fiscal (deficit) shock is defined as the difference between the expenditure and revenue shocks.
} 
qualitatively consistent with our finding but that his finding regarding taxes is not. The analogy, however, is far from obvious due to the different nature of the regressor in these papers, and to the fact that Poterba constructs an estimate of the unpredictable component of the budget surplus whereas we do not attempt to isolate the unpredictable component in GSP.

Despite the differences in sample and methodology, our reading of the overall results is that state and local government fiscal policy responds to the cycle with expenditure and taxes increasing in good times. The latter effect seems to dominate in the short run, resulting in procyclical surpluses. Poterba's (1994) analysis raises some questions as to why this happens and how governments determine fiscal policy-questions that we will not be able to answer in the present paper.

\section{Cyclical Properties of Capital Outlays}

In this section, we study the cyclical properties of state and local government capital outlays. In Tables 4 and 5, we reported the cyclical properties of state and local government expenditure. In those calculations we implicitly regarded all expenditure, including capital outlays, as consumption expenditure or transfers. Of course, certain capital outlays should be regarded as consumption (e.g., a more lavish mansion for the governor), but we cannot quantify which constitute "necessary" investment. In any event, the saving aspect of capital expenditure implies that the procyclicality of expenditure reported in Tables 4 and 5 may be overstated, an issue we address now.

Table 7 about here.

In Table 7 we display results confirming that capital outlays of both state and local governments are procyclical. The results displayed in this table are not sensitive to the inclusion of time-fixed effects. We, therefore, only present the results without time-fixed effects. Similarly, for the remainder of the paper, if the results are not sensitive to the inclusion of time-fixed effects, only results without time-fixed effects are displayed. For 
state governments, we can break down capital outlays into construction outlays, and land and equipment outlays. At the 1-year horizon, equipment outlays are slightly more procyclical than construction outlays, but at the 3-year horizon construction outlays are considerably more procyclical. ${ }^{36}$ A natural interpretation is that state governments quickly adjust expenditure on equipment, whereas construction projects (e.g., highways) are not quickly adjusted. Over longer horizons, expenditure on construction projects is adjusted and, therefore, follows output fluctuations more closely. ${ }^{37}$

Since the estimates in Table 7 are statistically significant and imply that capital outlays are procyclical, the estimates of the procyclicality of state and local government expenditure reported in the third column of Tables 4 and 5 are indeed likely to overstate the procyclicality of government spending on public goods and transfers. However, the point estimates in Table 7 are considerably smaller than the corresponding point estimates of procyclical government expenditure (especially for local governments). Therefore, controlling for the procyclicality of capital outlays does not alter the qualitative conclusions regarding the procyclicality of state and local government spending. ${ }^{38}$

\section{$5 \quad$ Is There Deficit Off-Loading?}

State and local governments control trust funds, utilities, and liquor stores (UILs) whose operations are not part of the official budget and, thus, are less conspicuous than other activities. Anecdotal evidence suggests that state and local governments are frequently tempted to shift deficits to these entities. For example, New Jersey governor Christine Whitman has on several occasions balanced the state budget by reducing the state government's payment to the state pension funds, ${ }^{39}$ while Indiana allocated $\$ 170$ Million of the

\footnotetext{
${ }^{36}$ Total Capital Outlays equals Construction Outlays plus Land and Equipment Outlays, but this identity is not imposed in the regressions.

${ }^{37}$ Gramlich (1991) finds that the ratio of (aggregate) state and local government construction expenditure to U.S. GNP responds negatively to the lagged unemployment rate.

${ }^{38}$ Notice that capital outlays (when regarded as investment) smooth consumption if they vary procyclically (assuming that the alternative use of a dollar spent on capital is consumption). Government consumption expenditure and transfers smooth consumption if they vary countercyclically.

${ }^{39}$ New York Times, April 22, 1997.
} 
budget surplus to the teachers' pension fund in fiscal (surplus) year $1998 .^{40}$

It is reasonable to conjecture that such behavior is exacerbated by the balanced budget restrictions that most U.S. states have adopted. ${ }^{41}$ The more stringent these restrictions, the stronger the incentive for such deficit shifting, an issue we shall explore in some detail. ${ }^{42}$

\subsection{Trust funds, utilities, and liquor stores}

Table 8 displays the cyclical properties of UIL budgets. The budget surpluses of liquor stores are acyclical - they are even weakly (and significantly) countercyclical at the 3-year frequency. This may reflect a countercyclical demand for liquor, i.e., people may buy more alcoholic beverages during slumps. Liquor store revenue is, however, a small and declining fraction of state and local government revenue, which is reflected in the tiny estimated coefficients, so we will not pursue the issue further. The budget surpluses of public utilities are procyclical, in particular at the local level. (The latter is not surprising as they are mainly managed by local governments.) Insurance trust fund surpluses are strongly procyclical at the state level, and this may partly reflect off-budgeting (deficit shifting). (The coefficients are small at the local level since trust funds are mainly managed by state governments.)

\footnotetext{
${ }^{40}$ USA Today, January 5, 1998. See also Bunch (1991) and Kiewiet and Szakaly (1996). Closely related is Inman and Mark (1998) who study the determinants of underfunding of U.S. state-level public employee pension plans - we describe their main results later.

${ }^{41}$ In virtually all states, balanced budget rules apply to the general fund, and in many states the rules also apply to other budget accounts such as the capital fund, or the federal funds account. State governments can run deficits even where balanced budget rules are tight as long as they have accumulated savings ((which are often accumulated in "rainy day funds.") See NASBO (1992), Bohn and Inman (1996), and Wagner (2000) for details. The balanced budget restrictions in the United States are mainly self-imposed by the states themselves but, in general, this need not be the case. von Hagen and Eichengreen (1996) explain why central governments may want to limit deficits of sub-central governments: if sub-central governments have less taxing power than central governments then central governments may be under pressure to bail out sub-central governments in a debt crisis. Anticipating this, higher level governments will impose limitations on the borrowing ability of lower level governments.

${ }^{42}$ The underlying theory is discussed in extensively in Drazen (2000). The logic can be summarized as follows. Time inconsistency is the greatest concern in implementing fiscal policy since ex-post, governments are often tempted to increase spending and raise taxes which affects incentives ex-ante (underinvestment, mis-reporting of income sources and so forth). Institutions, laws, and regulations that prevent opportunistic behavior by governments are a potential remedy; the harder it is to amend these laws and institutions the more credible the policy (hence the case for adopting constitutions that are very hard to change or repeal). Balanced budget rules are a prime example of an institution that is intended for precisely this purpose. Deficit off-loading through off-budget activities is a prime example of why institutions may not, after all, be effective as the discussion in Drazen (2000), chapter 5, suggests. See the analysis in Section 6.
} 
Table 8 about here.

All in all, the evidence is consistent with the idea that state and local governments systematically shift deficits to off-budget accounts. Such behavior would be consistent with the desire to smooth residents' income and consumption. If tax-collection costs are convex budget-by-budget then such behavior is also consistent with equalization of the fiscal burden at the margin across budgets.

There is nothing "wrong" with such behavior per se: a fiscal authority should make use of all the budgets at its disposal to achieve its goals (tax smoothing, consumption smoothing, or any other goal). The question is whether the use of an off-budget account as a fiscal tool is intended to circumvent balanced budget restrictions to the extent that the balanced budget rules do not effectively cover the off-budget accounts. We address this important issue later.

\subsection{Insurance Trust Funds: A Closer Look}

Unemployment insurance funds versus pension and other trust funds

The estimates of procyclical surpluses of insurance trust funds reported in Table 8 are based on a broad definition of state (and local) government-managed trust funds that includes unemployment insurance funds. Since state unemployment insurance trust funds are managed by the Treasury, and since there is federal legislation regarding minimum contributions and defining benefits, it would also make sense to regard unemployment contributions and benefits as part of the federal (rather than the state-level) tax-transfer system. The results in Table 8 may, thus, confound the role of the state and the federal levels of government.

On the other hand, there are good arguments for regarding unemployment insurance as a state-level institution, the main argument being that many states contribute beyond the minimum requirement imposed by the federal authorities. Rather than taking a stand on this issue, we decompose the trust fund surpluses to surpluses of unemployment insurance funds and of other (including pension) funds, and measure the cyclical properties of each 
class of funds separately. The results, displayed in the top panel of Table 9, indicate that both types of funds exhibit statistically significant procyclical surpluses at both differencing frequencies. ${ }^{43}$

Table 9 about here.

Pension fund assets and liabilities: is there buffer stock saving behavior?

So far we concentrated on the behavior of trust fund surpluses - a flow measure of the excess of current receipts over current expenses - in response to output fluctuations. It is also of interest to study the response of the stock of the assets managed by these funds to fluctuations in output. For example, acyclical behavior of the stock of assets would suggest that funds distribute more benefits (or raise less revenue) during booms, and vice versa during recessions, in order to maintain a constant stock of assets over the cycle. Procyclical behavior of assets would mean that funds accumulate a buffer stock of savings during booms to be run down during recessions. The more interesting variable to look at may be assets net of discounted future pension liabilities, since this amount of "over-funding" is in principle the correct measure of the net saving of a pension fund. Since over-funding is difficult to estimate, we report results using different measures of trust fund saving.

For pension funds we focus on two variables: financial assets of state public employee pension funds - the major subset of the trust funds considered above - and financial assets of these funds net of future pension liabilities. These variables were estimated following the econometric approach described in Inman (1986), and constructed by Robert Inman and Stephen Mark (1998). ${ }^{44}$ Define ASSETS $i t$ and NETASSETS $i t$ to be the change from year

\footnotetext{
${ }^{43}$ Since the pension and other trust fund surplus series look non-stationary, the results in the second column are calculated by regressing first-differenced surplus series on the first-differenced GSP series. Therefore, adding the coefficients from regressions for both types of funds (e.g., 0.39 and 0.18 for $k=1$ ) does not exactly yield the corresponding number reported in Table 8 (0.72 for $k=1)$. Inman and Mark (1998) study the time-series properties of the actuarial underfunding of state public employee pension plans, concluding that underfunding is a mean-reverting process. As is well known, unit root tests typically have low power, so it is hard to determine what exactly lies behind the different conclusion we reach regarding the time-series properties of the trust fund surplus. It may well be that the actuarial surplus, as calculated by Inman and Mark, is stationary, while the simple "pay-as-you-go" surplus is not.

${ }^{44}$ We are grateful to Inman and Mark for providing us their estimates of pension fund assets adjusted for the present value of accumulated pension liabilities.
} 
$t-1$ to year $t$ in the financial assets and the net assets (i.e., assets minus future liabilities), respectively, of the pension funds. ${ }^{45}$ In the bottom panel of Table 9, we display coefficients from the regressions of $\Delta \operatorname{ASSETS}_{i t}$ and $\operatorname{NETASSETS}_{i t}$ on $\Delta \mathrm{GSP}_{i t} \cdot{ }^{46}$ A positive regression coefficient is interpreted as buffer stock accumulation of assets. The results indicate clear and strong buffer stock saving behavior at the 3-year horizon for both series, and significant buffer stock behavior at the 1-year horizon for the series ASSETS $i t$.

We repeated the regressions allowing for time-fixed effects to examine if the results might be driven by U.S.-wide procyclical capital gains of pension funds (driven in turn by a general increase in asset prices). These regressions (details not reported) resulted in somewhat smaller coefficients for the buffering by assets alone, but the results for net assets are very similar.

\subsection{Off-budget accounts and balanced budget rules}

State governments are subject to restrictions on their ability to manipulate budgets. For example, from 1992 to 1994 California governor Pete Wilson withheld about \$700 million in pension plan contributions. However, this diversion was declared unconstitutional in court and the state government was ordered to repay. ${ }^{47}$ This anecdote clearly illustrates how big the temptation is for politicians to use off-budget accounts such as pension funds to alleviate revenue short-falls, even in the face of possible court reversals. This is consistent with our finding of statistically significant procyclicality of trust fund surpluses and we, therefore, pursue this issue in greater detail. Our goal is to determine whether state and local governments use off-budget accounts to circumvent such balanced budget restrictions.

Table 10 about here.

We first establish that these restrictions indeed affect fiscal behavior. Following Poterba

\footnotetext{
${ }^{45}$ The change in assets is comparable to the surpluses of the pension funds in the top panel of Table 9 .

${ }^{46}$ The NETASSETS $_{i t}$ series look stationary, while the ASSETS $i t$ series do not. Therefore, ASSETS $i t$ is firstdifferenced whereas NETASSETSit is not.

${ }^{47}$ Forbes, June 5, 1995.
} 
(1994), Eichengreen and Bayoumi (1994), Bohn and Inman (1996), and Alesina and Bayoumi (1996), we use the index of balanced budget stringency suggested in ACIR (1987) that ranks states on a scale of 0 to 10 (where 0 is the least stringent). There are 13 states with an index of 6 or lower, while the rest have an index of 8 or higher. No state has an index of 7 so we use 7 as our cut-off value for splitting the sample. ${ }^{48}$ The results for the low and high stringency sub-samples are displayed in Table $10 .{ }^{49}$ At the 1-year differencing frequency we find that the budget surpluses of states with more stringent budget rules exhibit less procyclicality: the P-values of the test statistic of the null hypothesis that there is no difference between the estimates for the two groups are 0.06 for the total surplus and 0.05 for the general surplus, confirming the general perception that fiscal discipline comes with a cost in the form of a reduced ability to respond to output fluctuations. Similar results were found by the above mentioned studies. The point estimates for 3 -year differencing and for local government surpluses are in the same direction as the results for 1-year differencing, but the differences between the estimates for the two groups are clearly small and not statistically significant. ${ }^{50}$

We turn to the question of deficit off-loading. We find no direct evidence of deficit off-loading intended to circumvent balanced budget restrictions. In states with stringent balanced budget rules, local governments do not exhibit stronger procyclicality of the surplus (nor do UILs). It is possible that we find no deficit off-loading to pension funds because balanced budget rules cover pension funds only in some states. A sharper test examines if there is more off-loading when balanced budget rules do not apply to trust funds. We

\footnotetext{
${ }^{48}$ The median state is not a good cut-off point for the sample since more than 25 states have an index of 10.

${ }^{49}$ In our setup, with cross-sectional fixed effects and state-specific error variances, splitting the sample is equivalent to estimating the model $s_{i t}=\alpha_{i}+\beta_{L} \mathrm{D}_{i}^{L} \Delta \mathrm{GSP}_{i t}+\beta_{H}\left(1-\mathrm{D}_{i}^{L}\right) \Delta \mathrm{GSP}_{i t}+\epsilon_{i t}$, where $s$ is the total surplus, GSP is gross state product, and $\mathrm{D}_{i}^{L}$ is a dummy variable which is 1 if state $i$ 's balanced budget rules are less stringent and 0 otherwise.

${ }^{50}$ Without a clear understanding of why governments adopt procyclical surpluses it is hard to say whether this empirical result is "good news" or "bad news". If one believes that procyclical surpluses (in particular, lower surpluses during slumps) help credit constrained individuals smooth consumption, then balanced budget restrictions limit the ability of governments to do so. An obvious counter-argument is that without such restrictions, fiscal discipline will be poor, forcing state and local governments to pay higher rates for funds, which will render them ineffective as providers of consumption smoothing. Furthermore, there is no consensus that governments should have such a role to begin with.
} 
classified states using to this criterion, ${ }^{51}$ finding no strong differences in the amount of procyclicality of pension fund surpluses and in the cyclical behavior of the assets of the funds across the two groups. This, again, indicates that the procyclical behavior of trust fund surpluses does not in general arise from attempts to circumvent balanced budget rules on the general budget. (Details not provided.)

\subsection{Historical debt levels}

Governments with a high level of debt may be more constrained in their ability to maintain procyclical budget surpluses. Alternatively, governments that are more prone to smoothing residents' consumption through procyclical surpluses may build up higher debt. To explore if there is a relation between debt levels and the cyclical properties of budget surpluses, we split the states according to the 1978 per capita levels of state government net long-term debt.

Table 11 about here.

Table 11 indicates that state governments with higher levels of debt exhibit more cyclical budget surpluses. This is true for the total and, in particular, the general surplus, for both 1-year differencing and 3-year differencing. These results are consistent with the view that high debt levels are a result of consumption smoothing through deficit spending (i.e., through procyclical surpluses), and that these debt levels are moderate enough so as not to interfere with the ability of state and local governments to use the budget as a tool for smoothing residents' consumption. ${ }^{52}$

It is conceivable that low historical long-term debt levels proxy for credit market imperfections, with poor states being more credit constrained. To explore this issue, we split the states according to wealth (per capita state GSP) and according to output growth,

\footnotetext{
${ }^{51}$ According to NASBO (1992), it is often a matter of judgment of state officials if generally worded balanced budget rules cover trust funds. NASBO (1992) estimates that balanced budget rules cover trust funds in 30 states.

${ }^{52}$ For OECD country-level governments, Arreaza, Sørensen, and Yosha (1999) find little correlation between the average size of the deficit and the amount of smoothing achieved through procyclical surpluses.
} 
and find (details not reported) that neither is correlated with the extent to which fiscal policy is procyclical. That is, historical debt levels do not simply proxy for credit market imperfections. Our favored interpretation is that a general "fiscally conservative" attitude in some states manifests itself in both low debt and little cyclical response to output shocks.

We carried out the test of the effect of long-term debt on the cyclicality of budget surpluses for local governments, using another criterion for splitting the sample: 1978 gross long-term debt, ${ }^{53}$ finding no significant effect. (Details not reported.) ${ }^{54}$

Disentangling the effect of balanced budget rules and of historical debt levels

Conceptually, the stringency of balanced budget rules is not independent of the level of long-term debt. Stringent budget rules may affect the debt level in a state directly by limiting the size of the deficit that the government can run, or may simply be correlated with debt levels since both reflect underlying attitudes to fiscal policy. Recalling that a high stringency index is associated with low procyclicality of the budget surplus (Table 10), and that a low historical debt level is also associated with low procyclicality of state-level budget surpluses (Table 11), it is natural to ask whether these effects are one and the same.

In order to provide some evidence on this question we go beyond the simple univariate regressions employed so far. First, we estimate the cyclical properties of the total state government budget for each state $i$ using the following time-series regression:

$$
\mathrm{S}_{i t}=\alpha_{i}+\beta_{i} \Delta \mathrm{GSP}_{i t}+\epsilon_{i t} .
$$

The coefficients for the individual states are estimated imprecisely, being based on short samples of time-series, but each estimate is unbiased and we can therefore perform a crosssectional multivariate regression of the form

$$
\hat{\beta}_{i}=\alpha_{0}+\alpha_{1} \log \operatorname{GSP}_{i}+\alpha_{2} \log \operatorname{LTDS}_{i, t_{0}}+\alpha_{3} \operatorname{INDEX}_{i}+\varepsilon_{i}
$$

\footnotetext{
${ }^{53}$ Offsets to gross local government debt are not available for 1978.

${ }^{54}$ We also split the states by the level of historical debt using 1984 as the starting year. We did so separately for state and local governments using net long-term debt issued by state and local governments, respectively. (For 1984, offsets were available for both state and local governments.) Hence, the sample is 1984-94. We found little difference between the results using 1978 as a starting year and those using 1984.
} 
where $\hat{\beta}_{i}$ is the estimated coefficient in equation (12), GSP $i$ is the average of GSP $i t$ over the sample years, $\operatorname{LTDS}_{i, t_{0}}$ is the level of long-term debt in 1978 (the first year of the sample) of state $i$ 's government, and INDEx $i$ is the balanced budget stringency index for state $i$. The estimated coefficients represent the marginal impact of each right-hand side variable on the procyclicality of the state government budget surplus. We include the level of output per capita as a regressor since a high level of wealth may itself facilitate procyclical surpluses, and a state's debt level need not be independent of the wealth of the state. By including both the debt level and the stringency index we can evaluate the marginal impact of each when the other is controlled for.

Table 12 about here.

The results, shown in Table 12, indicate that the historical debt level is positively related to surplus procyclicality, with the coefficient being significant at the 5 percent level at the 1-year frequency and weakly significant at the 3-year frequency, while the effect of the stringency of balanced budget rules is negative (as in the univariate regressions reported in Table 10) but not statistically significant.

These results are similar to the results obtained from splitting the sample: there we found a borderline significant impact of balanced budget rules at the 1-year horizon and a strong correlation with historical long-term debt (cf. the P-values in Tables 10 and 11). The t-statistics in the multivariate regression are lower, reflecting the small sample, but the qualitative conclusions are similar, indicating that our previous univariate regressions are sound..$^{55}$

As a final remark, our analysis is distinct from that of Bohn (1998) and Inman and Mark (1998) who are concerned with the sustainability of the debt level. Their empirical approach consists, essentially, of regressing the current surplus on the lagged level of debt. A positive coefficient reflects a tendency to reduce the debt whenever it is high which they

\footnotetext{
${ }^{55}$ The (simple) correlation of the balanced budget stringency index and state government long-term debt is -0.34 . Since the correlation is low, the univariate panel regressions regressions reported earlier will not be severely affected by left-out variable bias.
} 
interpret as a sustainable debt level. The extent to which the surplus is determined by output fluctuations as opposed to past debt levels remains an open empirical question.

\section{The Role of Fiscal and Political Institutions}

There is wide agreement regarding the role of institutions and, in particular, political institutions in shaping fiscal policy [see Poterba and von Hagen (1999), Alesina and Roubini (1997), Drazen (2000), and footnote 42]. We examine whether such considerations are important for the cyclical patterns of U.S. state and local government finances.

\subsection{Type of taxes more heavily used}

U.S. states differ in the mix of tax instruments used by state (and local) governments. ${ }^{56}$ We restrict attention to state personal income taxes, state general sales and gross receipts taxes, state severance taxes, and local property taxes. These components make up the bulk of state government revenue. Seventeen states do not have severance taxes. ${ }^{57}$ Severance taxes are typically small but they are important for states with large amounts of mining or oil extraction. We leave out the state corporate income tax which is relatively small for all states.

The tax revenue of state governments that rely on certain types of taxes may be more sensitive to output fluctuations. A pertinent example is oil states that rely heavily on severance taxes. The reliance on certain types of taxes may be a consequence of a particular attitude towards the use of fiscal policy to smooth fluctuations. For example, do states such as New Hampshire, that ideologically oppose personal income taxes, also oppose "fiscal activism" of the type we have been studying?

To address such questions, we classify states according to the share of particular types of taxes in the 1978 state or local government total tax revenue, and check whether the extent of surplus procyclicality varies systematically across groups. The results are displayed in Table 13. At the 3-year differencing frequency there are no significant differences across

\footnotetext{
${ }^{56}$ See Feenberg and Rosen (1986) for a comprehensive study.

${ }^{57}$ Recall that Alaska and Hawaii are not included in our sample.
} 
groups of states, but at the 1-year frequency we find that states with a higher share of state personal income taxes exhibit more procyclical budget surpluses. ${ }^{58}$ The opposite is true for general sales and gross receipts taxes and severance taxes. To check if our results are robust, we repeated the experiment using 1986 as the year for classifying states into groups and obtained qualitatively similar results.

Table 13 about here.

A potential interpretation is that reliance on personal income taxes - which are more directly tied to income than sales taxes - provides state governments with better tools for smoothing residents' income in response to output shocks. This is consistent with the smoothing impact of the personal income tax that is often remarked upon. ${ }^{59}$ For instance, State Budget \& Tax News, March 25, 1998, states: "Many states are revising their revenue estimates for the current fiscal year upward as tax collections continue to roll in. The upward revisions are particularly pronounced in jurisdictions with high reliance on personal income taxes ..." It is hard to determine whether the cyclical pattern of the budget surplus is solely due to "automatic stabilization of disposable income" or to voluntary behavior on the part of governments. At the 3-year horizon, where tax collection is more likely to reflect a choice by governments rather than institutional rigidities, we do not see a significant relation between a major tax source and the cyclicality of the surplus. We further examined if states with more progressive income taxes have more procyclical surpluses, using data reported (for 1983) in Feenberg and Rosen (1986). Surprisingly, we found no significant effects and we omit the details.

Of course, the tax structure itself is also endogenous, at least in the longer run, as are many other fiscal institutions. We do not explore this intriguing issue, but we do want to mention an interesting emerging literature that explores the idea that governments use fiscal

\footnotetext{
${ }^{58}$ Six states, Florida, Nevada, South Dakota, Texas, Washington, and Wyoming did not have state income taxes in 1978 .

${ }^{59}$ Table 13 displays the cyclicality of surpluses, but we verified that the different response of the surplus across states is driven by the revenue rather than the expenditure.
} 
policy to stabilize not only the income of residents but also the output (GDP) of the country they govern. Indeed, Gali (1994) and Fatas and Mihov (1999) find a negative relation between the size of government and the variability of output. (The latter paper extends this finding to the U.S. states as well.) Rodrik (1998) finds a positive relation between the size of government and the openness of countries and interprets this as evidence for more government-provided insurance in countries that are more exposed to risk emanating from foreign trade, e.g., terms of trade variability.

\subsection{Political institutions}

Consider a state governor, in an election year that occurs in the midst of an economic expansion. Most likely he (or she) will be tempted to spend the extra funds rather than increase saving. To test for such behavior, we construct for each state a dummy variable that takes the value one in a gubernatorial election year. ${ }^{60}$ We interact this dummy with another dummy variable that equals one if the growth of the state's GSP is above the average (for the state) in that year. The results, shown in Table 14, indicate that state governments refrain from accumulating a larger surplus in an election year that occurs in the midst of an upturn but (as we already know) do accumulate a larger surplus in expansions if there is no election. For downturns, no such asymmetry between election and non-election years is apparent. ${ }^{61}$

Table 14 about here.

Clearly, the temptation for incumbent politicians to spend more in election years is too large to resist. The lack of asymmetry between election and non-election years during recessions suggests that, despite the temptation to do so, state government politicians do not hand out election year tax cuts or boost popular spending in economic downturns.

\footnotetext{
${ }^{60}$ If, for example, the election takes place in 1990, the dummy variable equals one in 1989 since fiscal year 1989 is defined as the period July 1st 1989 to June 30th 1990.

${ }^{61}$ The regressions displayed in Table 14 do not include time-fixed effects. Similar (although somewhat weaker) results are obtained with time-fixed effects.
} 
There is no such asymmetry for national governments. ${ }^{62}$ We are aware of two potential explanations for this. ${ }^{63}$ The first is that voters punish politicians at the state and local government level for running large deficits in recessions. ${ }^{64}$ Presumably, other issues determine voting patterns in national elections. The second is that national governments can inflate their way out of deficits and thus may feel less constrained in election years even if these occur during a recession. ${ }^{65}$

\section{Additional tests}

We further divided the states according to whether they are "conservative" or not, using the classification developed in Erikson, Wright, and McIver (1993). The results, displayed in Table 15, indicate that the fiscal policy of conservative governments exhibits less procyclical budget surpluses. This is consistent with our interpretation that less surplus procyclicality in states with stringent balanced budget rules may reflect a general conservative attitude.

Table 15 about here.

We also studied whether the political variables "Democrat Governor," "United Legislature," and "United Executive and Legislative Branches" 66 affect the procyclicality of surpluses, and found no significant results. ${ }^{67}$ (Details not provided.)

\footnotetext{
${ }^{62}$ See, e.g., Alesina and Roubini (1997), chapter 7.

${ }^{63}$ We are grateful to Allan Drazen for suggesting them.

${ }^{64}$ See Peltzman (1992), and Brender (1999) for interesting evidence from Israel.

${ }^{65}$ See Drazen (2000) for a comprehensive discussion.

66 "United Legislature" refers to the number of times the bicameral (upper and lower) state legislatures were united (i.e., a majority of the same party in both). "United Branches" refers to the number of times the executive and the two legislative branches were united. Nebraska has a unicameral legislature and was dropped from these political groupings.

${ }^{67}$ The sample period, 1978-1994, was divided into two-year periods. (Governors are elected every four years, but not all states vote in the same year, and the legislature is elected every two years.) For each period we computed the average budget surplus and the average GSP, and attributed the appropriate political dummy variable to form two groups of observations.
} 


\section{Smoothing Income Fluctuations through State and Local Government Fiscal Policy}

Asdrubali, Sørensen, and Yosha (1996) estimate the fraction of idiosyncratic (state-specific) GSP fluctuations absorbed through various mechanisms: inter-state capital markets, the federal tax-transfer and grant system, and saving. Within their framework, the budget surplus is said to provide income smoothing if the growth rate of idiosyncratic disposal income + surplus reacts more strongly to idiosyncratic GSP growth fluctuations than disposable income itself. The intuition is simply that if the state government had lowered taxes so as not run a surplus, disposable income would have been higher.

For the sake of comparison with Asdrubali, Sørensen, and Yosha (1996), and to verify that the results presented here are qualitatively robust, we report estimates of income smoothing through state and local government fiscal surpluses using the method developed in that paper. ${ }^{68}$ It was found in that paper that 23 percent of idiosyncratic GSP fluctuations are absorbed via total (private + state government + local government) saving at the 1year frequency, and 7 percent of such fluctuations are absorbed at the 3 -year frequency. The amount of income smoothing obtained through state-level government surpluses and private saving were not estimated separately. ${ }^{69}$ We do so here. ${ }^{70}$

We employ the following simple methodology [see also Sørensen and Yosha (1999)]. Let $\mathrm{S}_{i t}$ denote the surplus of the government of state $i$ in period $t$ and let DPI ${ }_{i t}$ denote the state's disposable personal income. (Both variables in real per capita terms.) Intuitively, if the budget surplus smoothes disposable income, then -if U.S.-wide fluctuations are controlled for - the variable DPI $i t$ should be smoother than DPI $i t+\mathrm{S}_{i t}$. That is, in a "good year" for state $i$, the government of the state raises more taxes (the effective tax rate is higher) and runs a larger surplus whereas in a "bad year," the government raises less taxes and runs

\footnotetext{
${ }^{68}$ See Arreaza, Sørensen, and Yosha (1999) for a detailed discussion and application to OECD nationallevel fiscal policy.

${ }^{69}$ Such a decomposition for national OECD governments is provided in Sørensen and Yosha (1998).

${ }^{70} \mathrm{We}$ abstain from evaluating the welfare gains that such income smoothing generates. In general, the welfare effect of government-provided income and consumption smoothing depends on the degree to which individuals can smooth income and consumption on their own, which is likely to depend on many variables that are not studied in this paper such as demographics, poverty levels, and so on.
} 
a smaller surplus. Therefore, if this surplus were hypothetically rebated to residents, they would have at their disposal DPI $i t+\mathrm{S}_{i t}$ which is more volatile (less smooth) than their actual disposable income DPI $i t$. In other words, if the surplus indeed smooths GSP fluctuations, $\operatorname{DPI}_{i t}$ will vary less with GSP than $\mathrm{DPI}_{i t}+\mathrm{S}_{i t}$. More precisely, for the surplus to smooth income in this metric, idiosyncratic DPI $_{i t}$ needs to display a lower elasticity with respect to idiosyncratic GSP than $\operatorname{DPI}_{i t}+\mathrm{S}_{i t} \cdot{ }^{71}$ Income smoothing thus defined implies procyclicality of the budget surplus but not the other way around.

The coefficient $\beta$ in the following panel regression is a measure of the differential response of $\mathrm{DPI}_{i t}+\mathrm{S}_{i t}$ and $\mathrm{DPI}_{i t}$ to idiosyncratic GSP fluctuations:

$$
\Delta \log \left(\mathrm{DPI}_{i t}+\mathrm{S}_{i t}\right)-\Delta \log \mathrm{DPI}_{i t}=\nu_{t}+\beta \Delta \log \mathrm{GSP}_{i t}+u_{i t},
$$

where the $\nu_{t}$ parameters are time-fixed effects that control for year-specific aggregate fluctuations. ${ }^{72}$

Table 16 about here.

The results, displayed in Table 16, indicate that state and local government fiscal policy indeed provides smoothing (which is fully consistent with the analysis in previous sections). The results at both frequencies reveal that 3.7 percent $(3.01+0.73$ at the 1 -year frequency and $2.94+0.78$ at the 3-year frequency) of idiosyncratic shocks to GSP are absorbed through state and local government fiscal policy. This is not a negligible number, although it is small in comparison with the amount of smoothing through the budget achieved by national OECD governments: Sørensen and Yosha (1998) find that 25 to 30 percent of GDP shocks are smoothed through government saving in OECD countries, at both the 1-year and 3-year horizons. The amount of state and local government income smoothing is also

\footnotetext{
${ }^{71}$ Eichengreen and Bayoumi (1994) consider the reaction of the surplus/income ratio to GSP growth. This is close - but not identical - to this measure.

${ }^{72}$ In this regression, we do not include cross-sectional fixed effects. The estimated coefficients can then be shown to be weighted averages of the coefficients of the year by year cross-sectional regressions; see Asdrubali, Sørensen, and Yosha (1996), footnote 5. Regressions with both time- and cross-sectional fixed effects give similar results (not shown).
} 
small relative to the 23 percent found for total smoothing via saving at the 1-year horizon in Asdrubali, Sørensen, and Yosha (1996). However, the number makes up about half of the smoothing by total saving (7 percent) at the 3 -year horizon. This may reflect that governments are better able to borrow over longer horizons, or it may reflect governmental inertia (for example, in adjusting tax-rates) - a much more detailed study will be needed to sort out these issues. ${ }^{73}$

\section{Concluding Remark}

Our analysis provides a set of stylized facts for structural models to match. One obviousbut we believe difficult - task is to derive models for the optimal cyclical behavior of state and local government budget surpluses, for the optimal mix of expenditure and revenue, for the adjustment of wealth buffer stocks (rainy day funds), and for borrowing and lending out-of-state. A related challenging task is to model the optimal "division of labor" among various levels of government in financing public goods and raising tax revenue. We believe that our findings in this paper can help construct such models.

\footnotetext{
${ }^{73}$ Our results in this section are broadly comparable with those of Eichengreen and Bayoumi (1994); see footnote 71 .
} 


\section{References}

Advisory Commission on Intergovernmental Relations (ACIR), 1987. Fiscal Discipline in a Federal System: Experience of the States. Washington, D.C.

Arreaza, A., Sørensen, B.E., Yosha, O., 1999. Consumption smoothing through fiscal policy in OECD and EU countries. In: Poterba, J. von Hagen, J. (Eds.), Fiscal Institutions and Fiscal Performance. Chicago University Press, Chicago.

Alesina, A., Bayoumi, T., 1996. The cost and benefit of fiscal rules: Evidence from U.S. states. Working Paper no. 5614. NBER, Cambridge, MA.

Alesina, A., Roubini, N. with Cohen, G., 1997. Political Cycles and the Macroeconomy. MIT Press, Cambridge, MA.

Asdrubali, P., Sørensen, B.E., Yosha, O., 1996. Channels of interstate risk sharing: United States 1963-90. Quarterly Journal of Economics 111, 1081-1110.

Auerbach, A., 1994. The U.S. fiscal problem: Where we are, how we got here, and where we're going (and comments by Feldstein, M. and Chari, V.V.). NBER Macroeconomics Annual 1994, 141-186.

Bennett, J., DiLorenzo, T., 1983. Underground Government: The Off-Budget Public Sector. CATO Institute, Washington D.C.

Bohn, H., 1998. The behavior of public debt and deficits. Quarterly Journal of Economics 113, 949-963.

Bohn, H., Inman, R., 1996. Balanced-budget rules and public deficits: Evidence from the U.S. states. Carnegie-Rochester Conference Series on Public Policy 45, 13-76.

Brender, A., 1999. The effect of fiscal performance on local government election results in Israel: 1989-1998. Mimeo. Bank of Israel.

Bunch, B., 1991. The effect of constitutional debt limits on state governments' use of public authorities. Public Choice 69, 57-69.

Drazen, A., 2000. Political Economy in Macroeconomics. Princeton University Press, Princeton, New Jersey.

Eichengreen, B., Bayoumi, T., 1994. The political economy of fiscal restrictions: Implications for Europe from the United States. European Economic Review 38, 783-791.

Erikson, R., Wright, G., McIver, J., 1993. Statehouse Democracy: Public Opinion and Policy in the American States. Cambridge University Press, Cambridge, UK.

Fatas, A., Mihov, I., 1999. Government size and automatic stabilizers: International and intranational evidence. Discussion Paper no. 2259. CEPR, London. 
Feenberg, D., Rosen, H., 1986. State personal income and sales taxes, 1977-1983. In Rosen, H. (Ed.), Fiscal Policy and Fiscal Institutions. University of Chicago Press, Chicago.

Gali, J., 1994. Government size and macroeconomic stability. European Economic Review $38,117-132$.

Gavin, M., Perotti,R., 1997. Fiscal policy in Latin America. NBER Macroeconomics Annual 1997, 11-61.

Goodhart, C., Smith, S., 1993. Stabilization, European Economy, reports and studies no. $5,419-55$.

Gramlich E., 1991. The 1991 state and local fiscal crises. Brookings Papers on Economic Activity 2, 249-275.

von Hagen, J., 1992. Fiscal arrangements in a monetary union: Evidence from the US. In: Fair, D., de Boissieu, C. (Eds.), Fiscal Policy, Taxation, and the Financial System in an Increasingly Integrated Europe. Kluwer, Boston.

von Hagen, J., Eichengreen, B., 1996. Federalism, fiscal restraints, and European monetary union. American Economic Review, Papers and Proceedings 86, 134-138.

Inman, R., 1986. Appraising the funding status of teacher pensions: An econometric approach. National Tax Journal 39, 21-33.

Inman, R., Mark, S., 1998. Funding state public employee pension plans. Mimeo. University of Pennsylvania.

Kalemli-Ozcan, S., Sørensen, B.E., Yosha,O., 2000. Capital market integration, industrial specialization, and the asymmetry of macroeconomic fluctuations. Journal of International Economics, forthcoming.

Kiewiet, R., Szakaly, K., 1996. Constitutional limitations on borrowing: An analysis of state bonded indebtedness. Journal of Law, Economics, and Organization 12, 6297.

Lane, P., 1999. The cyclical behavior of fiscal policy: Evidence from the OECD. Mimeo. University of Dublin.

Lane, P., Tornell, A., 1998a. The political economy of fiscal restrictions: Implications for Europe from the United States. European Economic Review 38, 783-791.

Lane, P., Tornell, A., 1998b. Why aren't Latin American savings rates procyclical? Journal of Development Economics 57, 185-200.

National Association of State Budget Officers (NASBO), 1992. State Balanced Budget Requirements: Provisions and Practice. Washington, D.C.

Peltzman, S., 1992. Voters as fiscal conservatives. Quarterly Journal of Economics 107, $327-361$. 
Poterba, J., 1994. State responses to fiscal crises: The effects of budgetary institutions and politics. Journal of Political Economy 102, 798-821.

Poterba, J., von Hagen, J., 1999. Fiscal policy and fiscal institutions. University of Chicago Press, Chicago.

Rodrik, D., 1998. Why do more open economies have bigger governments? Journal of Political Economy 106, 997-1032.

Rogoff, K., 1990. Equilibrium political budget cycles. American Economic Review 80, 2136.

Rosen, H., Feenberg, D., 1986. State personal income and sales taxes, 1977-1983. In Rosen, H. (Ed.), Fiscal Policy and Fiscal Institutions. University of Chicago Press, Chicago.

Sala-i-Martin, X., Sachs, J., 1992. Fiscal federalism and optimum currency areas: Evidence for Europe from the United States. In Establishing A Central Bank: Issues in Europe and Lessons from the U.S.. Canzoneri, M., Masson,P., Grilli, V. (Eds.), Cambridge University Press, London, UK.

Sørensen, B.E., Yosha, O., 1998. International risk sharing and European monetary unification. Journal of International Economics 45, 211-238.

Sørensen, B.E., Yosha, O., 1999. Federal insurance of US states: An empirical investigation. In Razin, A., Sadka, E. (Eds.), Globalization: A Public Finance Perspective. Cambridge University Press, New York.

State Policy Reports, 1998. Vol. 16, various issues.

Stein, E., Talvi, E., Grisanti, A., 1998. Institutional arrangements and fiscal performance: The Latin American experience. Working Paper no. 6358. NBER, Cambridge, MA.

Talvi, E., Vègh, C., 1998. Tax base variability and procyclical fiscal policy. Mimeo. UCLA.

Tornell, A., Lane, P., 1999. The voracity effect. American Economic Review 89, 22-46.

Velasco, A., 1999. A model of endogenous fiscal deficits and delayed fiscal reforms. In: Poterba, J., von Hagen, J. (Eds.), Fiscal Institutions and Fiscal Performance. Chicago University Press, Chicago.

Wagner, G., 2000. Are state budget stabilization funds only the illusion of savings? Mimeo. West Virginia University. 
Table 1: State and Local Government Per Capita

Surplus, Revenue, and Expenditure (Dollars)

\begin{tabular}{|c|c|c|c|}
\hline & & $\begin{array}{r}\text { State Governments } \\
1978-94\end{array}$ & $\begin{array}{r}\text { Local Governments } \\
1978-94\end{array}$ \\
\hline General & mean & 45 & 30 \\
\hline \multirow[t]{2}{*}{ Surplus } & std1 & 93 & 58 \\
\hline & $\operatorname{std} 2$ & 64 & 48 \\
\hline \multirow[t]{3}{*}{ Revenue } & mean & 1492 & 1273 \\
\hline & std1 & 325 & 337 \\
\hline & $\operatorname{std} 2$ & 202 & 135 \\
\hline \multirow[t]{3}{*}{ Expenditure } & mean & 1447 & 1243 \\
\hline & std1 & 283 & 318 \\
\hline & $\operatorname{std} 2$ & 207 & 147 \\
\hline Insurance & mean & 111 & 8 \\
\hline Trusts & std 1 & 76 & 13 \\
\hline Surplus & std2 & 51 & 7 \\
\hline Utilities & mean & -18 & -39 \\
\hline \multirow[t]{2}{*}{ Surplus } & std1 & 26 & 59 \\
\hline & $\operatorname{std} 2$ & 11 & 25 \\
\hline Liquor & mean & 9 & 3 \\
\hline Stores & std1 & 7 & 2 \\
\hline Surplus & $\operatorname{std} 2$ & 3 & 1 \\
\hline
\end{tabular}

Notes. "std1" (cross-section): time average of $\left[(1 / n) \sum_{i}\left(X_{i t}-\bar{X}_{t}\right)^{2}\right]^{1 / 2}$ where $\bar{X}_{t}$ is the period $t$ average of $X_{i t}$ across states, and $n$ is the number of states. "std2" (time-series): average over $i$ of $\left[(1 / T) \sum_{t}\left(X_{i t}-\bar{X}_{i}\right)^{2}\right]^{1 / 2}$ where $\bar{X}_{i}$ is the time average of $X_{i t}$ for state $i$, and $T$ is the number of years in the sample.

Real per capita 1983 dollars. General Surplus: does not include revenue and expenditure of utilities, liquor stores, and insurance trust funds. Insurance Trusts: 48 state-run; 44 local-run. Utilities: 13 state-run; 48 local-run. Liquor Stores: 17 state-run; 4 local-run. Averages and standard deviations are calculated including only states where the relevant budget component is non-zero. 
Table 2: Intergovernmental Net Per Capita Transfers

\begin{tabular}{lrrr}
\hline \hline & & & \% GSP \\
& & $1978-94$ & in 1994 \\
& & & \\
\hline \multirow{2}{*}{ Federal to State } & mean & 379 & 3.1 \\
& std1 & 100 & - \\
& std2 & 64 & - \\
Federal to Local & mean & 72 & 0.3 \\
& std1 & 21 & - \\
& std2 & 25 & - \\
& & & 2.9 \\
& mean & 426 & - \\
\hline \hline
\end{tabular}

Notes. "std1" (cross-section): time average of $\left[(1 / n) \sum_{i}\left(X_{i t}-\bar{X}_{t}\right)^{2}\right]^{1 / 2}$ where $\bar{X}_{t}$ is the period $t$ average of $X_{i t}$ across states, and $n$ is the number of states. "std2" (time-series): average over $i$ of $\left[(1 / T) \sum_{t}\left(X_{i t}-\bar{X}_{i}\right)^{2}\right]^{1 / 2}$ where $\bar{X}_{i}$ is the time average of $X_{i t}$ for state $i$, and $T$ is the number of years in the sample. The column "\% GSP " displays the amount of the relevant transfer aggregated across states as a fraction of GDP (=GSP aggregated across states).

Real per capita 1983 dollars. All state and local governments receive revenue from the federal government. All local governments receive revenue from their state government. 
Table 3: Cyclical Patterns of the Total Surplus of State and Local Government Budgets

\begin{tabular}{|c|c|c|}
\hline & $k=1$ & $k=3$ \\
\hline \multicolumn{3}{|c|}{ Without Time-Fixed Effects ${ }^{1}$} \\
\hline State & $\begin{array}{c}2.98 \\
(8.25)\end{array}$ & $\begin{array}{c}8.62 \\
(14.99)\end{array}$ \\
\hline Local & $\begin{array}{c}0.92 \\
(4.72)\end{array}$ & $\begin{array}{c}2.57 \\
(9.73)\end{array}$ \\
\hline \multicolumn{3}{|c|}{ With Time-Fixed Effects ${ }^{2}$} \\
\hline State & $\begin{array}{c}3.12 \\
(6.01)\end{array}$ & $\begin{array}{c}9.35 \\
(11.68)\end{array}$ \\
\hline Local & $\begin{array}{c}0.35 \\
(1.34)\end{array}$ & $\begin{array}{c}1.69 \\
(5.26)\end{array}$ \\
\hline
\end{tabular}

Notes. ${ }^{1}$ Coefficient $\hat{\beta}$ from regression $s_{i t}=\alpha_{i}+\beta \Delta \mathrm{GSP}_{i t}+\epsilon_{i t}$, where $s$ is the total surplus, GSP is gross state product, and $\alpha_{i}$ are cross-sectional fixed effects.

${ }^{2}$ Coefficient $\hat{\beta}$ from regression $s_{i t}=\alpha_{i}+\nu_{t}+\beta \Delta \operatorname{GSP}_{i t}+\epsilon_{i t}$, where $\nu_{t}$ are time-fixed effects. The " $k=3$ " column reports the $\hat{\beta}$-coefficient from a regression of $s_{i t}+s_{i, t-1}+s_{i, t-2}$ on GSP $_{i t}-$ GSP $_{i, t-3}$ using non-overlapping data, allowing for fixed effects. Estimates are scaled by 100 to reflect the response of the corresponding budget surplus to a $\$ 100$ increase in per capita gross state product.

Real per capita 1983 dollars. t-statistics in parentheses. Total Surplus includes revenue and expenditure of utilities, liquor stores, and insurance trust funds. OASDI = federal old-age, survivors' and disability insurance. Sample period: 1978-1994. 
Table 4: Cyclical Patterns of State Government Budget Components

\begin{tabular}{|c|c|c|c|}
\hline & Federal Grants & Own Revenue & Expenditure \\
\hline \multicolumn{4}{|c|}{ Without Time-Fixed Effects ${ }^{1}$} \\
\hline$k=1$ & $\begin{array}{c}0.43 \\
(2.89)\end{array}$ & $\begin{array}{c}5.42 \\
(17.92)\end{array}$ & $\begin{array}{c}1.01 \\
(2.94)\end{array}$ \\
\hline$k=3$ & $\begin{array}{c}1.01 \\
(8.43)\end{array}$ & $\begin{array}{c}6.37 \\
(25.47)\end{array}$ & $\begin{array}{c}2.95 \\
(8.98)\end{array}$ \\
\hline \multicolumn{4}{|c|}{ With Time-Fixed Effects ${ }^{2}$} \\
\hline$k=1$ & $\begin{array}{c}-0.35 \\
(-2.35)\end{array}$ & $\begin{array}{c}3.17 \\
(7.89)\end{array}$ & $\begin{array}{c}0.53 \\
(1.46)\end{array}$ \\
\hline$k=3$ & $\begin{array}{c}-0.48 \\
(-3.54)\end{array}$ & $\begin{array}{c}5.94 \\
(14.58)\end{array}$ & $\begin{array}{c}1.33 \\
(4.28)\end{array}$ \\
\hline
\end{tabular}

Notes. ${ }^{1}$ Coefficient $\hat{\beta}$ from regression $\Delta X_{i t}=\alpha_{i}+\beta \Delta \mathrm{GSP}_{i t}+\epsilon_{i t}$, where $X$ is the budget component indicated in the column title and GSP is gross state product.

${ }^{2}$ Coefficient $\hat{\beta}$ from regression $\Delta X_{i t}=\alpha_{i}+\nu_{t}+\beta \Delta \mathrm{GSP}_{i t}+\epsilon_{i t}$.

The " $k=3$ " rows report the $\hat{\beta}$-coefficient from a regression of $X_{i t}-X_{i, t-3}$ on $\operatorname{GSP}_{i t}-\operatorname{GSP}_{i, t-3}$ using non-overlapping data, allowing for fixed effects. Estimates are scaled by 100 to reflect the response of the corresponding budget surplus to a $\$ 100$ increase in per capita gross state product. The budget components refer to the total state government budget including utilities, insurance trusts, and liquor stores.

Real per capita 1983 dollars. t-statistics in parentheses. Note that although Total Surplus $=$ Federal Grants + Own Revenue - Expenditure, the coefficients associated with these individual components will not add up to the coefficient for state government total surplus reported in Table 3 since the individual budget components are first-differenced (being non-stationary) whereas in the regressions reported in Table 3 the state government total surplus is not differenced (as it is stationary). Sample period: 1978-1994. 
Table 5: Cyclical Patterns of Local Government Budget Components

\begin{tabular}{|c|c|c|c|c|}
\hline & Federal Grants & State Grants & Own Revenue & Expenditure \\
\hline \multicolumn{5}{|c|}{ Without Time-Fixed Effects ${ }^{1}$} \\
\hline$k=1$ & $\begin{array}{c}0.14 \\
(2.70)\end{array}$ & $\begin{array}{c}0.89 \\
(7.05)\end{array}$ & $\begin{array}{c}1.66 \\
(8.47)\end{array}$ & $\begin{array}{c}1.53 \\
(5.19)\end{array}$ \\
\hline$k=3$ & $\begin{array}{c}0.20 \\
(3.12)\end{array}$ & $\begin{array}{c}1.51 \\
(10.24)\end{array}$ & $\begin{array}{c}2.35 \\
(17.24)\end{array}$ & $\begin{array}{c}3.42 \\
(12.67)\end{array}$ \\
\hline \multicolumn{5}{|c|}{ With Time-Fixed Effects ${ }^{2}$} \\
\hline$k=1$ & $\begin{array}{c}-0.08 \\
(-1.33)\end{array}$ & $\begin{array}{c}0.24 \\
(1.44)\end{array}$ & $\begin{array}{c}0.17 \\
(0.71)\end{array}$ & $\begin{array}{c}-0.42 \\
(-1.26)\end{array}$ \\
\hline$k=3$ & $\begin{array}{c}-0.11 \\
(-1.88)\end{array}$ & $\begin{array}{c}1.17 \\
(5.76)\end{array}$ & $\begin{array}{c}0.72 \\
(2.10)\end{array}$ & $\begin{array}{c}2.26 \\
(6.03)\end{array}$ \\
\hline
\end{tabular}

Notes. ${ }^{1}$ Coefficient $\hat{\beta}$ from regression $\Delta X_{i t}=\alpha_{i}+\beta \Delta \mathrm{GSP}_{i t}+\epsilon_{i t}$, where $X$ is the budget component indicated in the column title and GSP is gross state product.

${ }^{2}$ Coefficient $\hat{\beta}$ from regression $\Delta X_{i t}=\alpha_{i}+\nu_{t}+\beta \Delta \mathrm{GSP}_{i t}+\epsilon_{i t}$.

The " $k=3$ " rows report the $\hat{\beta}$-coefficient from a regression of $X_{i t}-X_{i, t-3}$ on $\mathrm{GSP}_{i t}-\mathrm{GSP}_{i, t-3}$ using non-overlapping data, allowing for fixed effects. Estimates are scaled by 100 to reflect the response of the corresponding budget surplus to a $\$ 100$ increase in per capita gross state product. The budget components refer to the total budget including utilities, insurance trusts, and liquor stores.

Real per capita 1983 dollars. t-statistics in parentheses. Note that although Total Surplus $=$ Federal Grants + State Grants + Own Revenue - Expenditure, the coefficients associated with these individual components will not add up to the coefficient for local government total surplus reported in Table 3 since the individual budget components are first-differenced (being non-stationary) whereas in the regressions reported in Table 3 the local government total surplus is not differenced (as it is stationary). Sample period: 1978-1994. 
Table 6: Dynamic Response of State Government Budget Components to GSP Fluctuations

\begin{tabular}{|c|c|c|c|c|c|c|}
\hline \multicolumn{7}{|c|}{ Regression: $y_{i t}=\alpha_{i}\left(+\nu_{t}\right)+\beta_{0} \Delta \operatorname{GSP}_{i, t}+\beta_{1} \Delta \operatorname{GSP}_{i, t-1}+\beta_{2} \Delta \operatorname{GSP}_{i, t-2}+\cdots+\beta_{5} \Delta \operatorname{GSP}_{i, t-5}+\epsilon_{i t}$} \\
\hline & \multicolumn{3}{|c|}{ Without Time-Fixed Effects } & \multicolumn{3}{|c|}{ With Time-Fixed Effects } \\
\hline$y_{i t}$ : & Revenue & Expenditure & Surplus & Revenue & Expenditure & Surplus \\
\hline$\beta_{0}$ & $\begin{array}{c}5.21 \\
(12.54)\end{array}$ & $\begin{array}{c}1.71 \\
(4.54)\end{array}$ & $\begin{array}{c}4.33 \\
(10.52)\end{array}$ & $\begin{array}{c}2.43 \\
(4.61)\end{array}$ & $\begin{array}{c}0.19 \\
(0.48)\end{array}$ & $\begin{array}{c}3.34 \\
(6.03)\end{array}$ \\
\hline$\beta_{1}$ & $\begin{array}{c}1.67 \\
(4.06)\end{array}$ & $\begin{array}{c}0.19 \\
(0.51)\end{array}$ & $\begin{array}{c}4.54 \\
(10.51)\end{array}$ & $\begin{array}{c}0.40 \\
(0.69)\end{array}$ & $\begin{array}{c}0.28 \\
(0.62)\end{array}$ & $\begin{array}{c}3.65 \\
(6.02)\end{array}$ \\
\hline$\beta_{2}$ & $\begin{array}{l}1.06 \\
(2.35)\end{array}$ & $\begin{array}{c}3.68 \\
(9.24)\end{array}$ & $\begin{array}{c}1.71 \\
(4.15)\end{array}$ & $\begin{array}{l}1.43 \\
(2.44)\end{array}$ & $\begin{array}{c}2.55 \\
(5.36)\end{array}$ & $\begin{array}{c}1.57 \\
(2.63)\end{array}$ \\
\hline$\beta_{3}$ & $\begin{array}{c}-2.56 \\
(-7.19)\end{array}$ & $\begin{array}{c}-1.27 \\
(-3.41)\end{array}$ & $\begin{array}{l}1.11 \\
(2.88)\end{array}$ & $\begin{array}{c}-0.44 \\
(-0.80)\end{array}$ & $\begin{array}{c}0.76 \\
(1.70)\end{array}$ & $\begin{array}{c}0.05 \\
(0.10)\end{array}$ \\
\hline$\beta_{4}$ & $\begin{array}{c}0.35 \\
(0.79)\end{array}$ & $\begin{array}{c}1.26 \\
(3.37)\end{array}$ & $\begin{array}{l}1.07 \\
(2.73)\end{array}$ & $\begin{array}{c}0.33 \\
(0.61)\end{array}$ & $\begin{array}{c}1.43 \\
(3.50)\end{array}$ & $\begin{array}{c}-0.43 \\
(-0.79)\end{array}$ \\
\hline$\beta_{5}$ & $\begin{array}{c}1.52 \\
(4.18)\end{array}$ & $\begin{array}{c}1.11 \\
(3.22)\end{array}$ & $\begin{array}{c}0.40 \\
(1.20)\end{array}$ & $\begin{array}{c}1.34 \\
(2.67)\end{array}$ & $\begin{array}{c}0.02 \\
(0.05)\end{array}$ & $\begin{array}{c}0.32 \\
(0.62)\end{array}$ \\
\hline
\end{tabular}

Notes. Revenue equals Own Revenue plus Federal Grants. These budget components refer to the total state government budget including utilities, insurance trusts, and liquor stores. Revenue and Expenditure are first-differenced at the 1-year frequency. All the variables in these regressions are stationary. Real per capita 1983 dollars. t-statistics in parentheses. Sample period: 1978-1994. The results for the consolidated budgets of state and local governments are similar. 
Table 7: Cyclical Patterns of

State and Local Government Capital Outlays

\begin{tabular}{|c|c|c|c|c|}
\hline & & $\begin{array}{c}\text { Total Capital } \\
\text { Outlays }\end{array}$ & $\begin{array}{c}\text { Construction } \\
\text { Outlays }\end{array}$ & $\begin{array}{c}\text { Land and } \\
\text { Equipment Outlays }\end{array}$ \\
\hline \multirow[t]{2}{*}{ State } & $k=1$ & $\begin{array}{c}0.40 \\
(3.59)\end{array}$ & $\begin{array}{c}0.13 \\
(1.29)\end{array}$ & $\begin{array}{c}0.17 \\
(5.62)\end{array}$ \\
\hline & $k=3$ & $\begin{array}{c}1.02 \\
(10.13)\end{array}$ & $\begin{array}{c}0.52 \\
(5.89)\end{array}$ & $\begin{array}{c}0.15 \\
(3.74)\end{array}$ \\
\hline \multirow[t]{2}{*}{ Local } & $k=1$ & $\begin{array}{c}0.07 \\
(0.55)\end{array}$ & - & - \\
\hline & $k=3$ & $\begin{array}{c}0.98 \\
(7.19)\end{array}$ & - & - \\
\hline
\end{tabular}

Notes. Coefficient $\hat{\beta}$ from regression $\Delta X_{i t}=\alpha_{i}+\beta \Delta \mathrm{GSP}_{i t}+\epsilon_{i t}$, where $X$ is the budget component indicated in the column title and GSP is gross state product.

The " $k=3$ " rows report the $\hat{\beta}$-coefficient from a regression of $X_{i t}-X_{i, t-3}$ on GSP $i t-\operatorname{GSP}_{i, t-3}$ using non-overlapping data, allowing for cross-sectional fixed effects. Estimates are scaled by 100 to reflect the response of the corresponding budget component to a $\$ 100$ increase in per capita gross state product. The capital outlays refer to the total state government budget including utilities, insurance trusts, and liquor stores.

Real per capita 1983 dollars. t-statistics in parentheses. Capital Outlays $=$ Construction Outlays + Land and Equipment Outlays. Construction and Land and Equipment Outlays data are not available for the whole sample period for local governments. Sample period: 1978-1994. Time-fixed effects not included. 
Table 8: Cyclical Patterns of the Budget Surplus of Utilities, Insurance Trust Funds, and Liquor Stores

\begin{tabular}{cccc}
\hline \hline Utilities & Trust Funds & Liquor Stores \\
$k=1 \quad k=3 \quad k=1 \quad k=3$ & $k=1 \quad k=3$ \\
\hline
\end{tabular}

Without Time-Fixed Effects ${ }^{1}$

$\begin{array}{ccccccc}\text { State } & -0.00 & 0.19 & 0.72 & 2.56 & -0.02 & -0.08 \\ & (-0.01) & (3.68) & (4.20) & (7.34) & (-1.61) & (-2.11) \\ \text { Local } & 0.08 & 0.38 & 0.01 & 0.11 & -0.00 & -0.02 \\ & (1.80) & (5.22) & (2.50) & (3.83) & (-0.54) & (-0.78)\end{array}$

Notes. ${ }^{1}$ Coefficient $\hat{\beta}$ from regression $s_{i t}=\alpha_{i}+\beta \Delta \mathrm{GSP}_{i t}+\epsilon_{i t}$, where $s$ is the total surplus and GSP is gross state product.

The " $k=3$ " column reports the $\hat{\beta}$-coefficient from a regression of $s_{i t}+s_{i, t-1}+s_{i, t-2}$ on GSP $i t-\operatorname{GSP}_{i, t-3}$ using non-overlapping data, allowing for cross-sectional fixed effects. Estimates are scaled by 100 to reflect the response of the corresponding budget surplus to a $\$ 100$ increase in per capita gross state product.

Real per capita 1983 dollars. t-statistics in parentheses. Sample period: 1978-1994. 
Table 9: Insurance Trust Funds: A Closer Look

\begin{tabular}{|c|c|c|}
\hline \multicolumn{3}{|c|}{$\begin{array}{l}\text { Unemployment Insurance Funds } \\
\text { versus Pension Funds and Other Trust Funds }\end{array}$} \\
\hline & $\begin{array}{l}\text { Unemployment } \\
\text { Insurance }^{1}\end{array}$ & Pension and Other ${ }^{2}$ \\
\hline$k=1$ & $\begin{array}{c}0.39 \\
(5.32)\end{array}$ & $\begin{array}{c}0.18 \\
(2.68)\end{array}$ \\
\hline$k=3$ & $\begin{array}{c}0.97 \\
(8.40)\end{array}$ & $\begin{array}{c}0.78 \\
(6.61)\end{array}$ \\
\hline \multicolumn{3}{|c|}{$\begin{array}{l}\text { Pension Fund Assets and Liabilities: } \\
\text { Do Pension Fund Assets Buffer Output Shocks? }\end{array}$} \\
\hline & Assets $^{3}$ & $\begin{array}{c}\text { Assets Less } \\
\text { Pension Liabilities }{ }^{3}\end{array}$ \\
\hline$k=1$ & $\begin{array}{c}0.51 \\
(1.85)\end{array}$ & $\begin{array}{c}0.07 \\
(0.14)\end{array}$ \\
\hline$k=3$ & $\begin{array}{c}2.61 \\
(3.96)\end{array}$ & $\begin{array}{c}2.67 \\
(5.19)\end{array}$ \\
\hline
\end{tabular}

Notes. ${ }^{1}$ Coefficient $\hat{\beta}$ from regression $X_{i t}=\alpha_{i}+\beta \Delta \mathrm{GSP}_{i t}+\epsilon_{i t}$, where $X$ is the surplus of the unemployment trust fund and GSP is gross state product.

${ }^{2}$ Coefficient $\hat{\beta}$ from regression $\Delta X_{i t}=\alpha_{i}+\beta \Delta \operatorname{GSP}_{i t}+\epsilon_{i t}$, where $X$ is the (non-stationary) surplus of pension and other trust funds.

${ }^{3}$ Coefficient $\hat{\beta}$ from regression $\Delta X_{i t}=\alpha_{i}+\beta \Delta \mathrm{GSP}_{i t}+\epsilon_{i t}$, where $X$ is the change in the pension fund assets. For "Assets Less Pension Liabilities", replace $\Delta X_{i t}$ with $X_{i t}$. " $k=3$ ": see notes to previous tables. Estimates are scaled by 100 to reflect the response of the corresponding budget surplus to a $\$ 100$ increase in per capita gross state product.

Real per capita 1983 dollars. t-statistics in parentheses. "Pension" refers to the employeeretirement systems of state and local governments. "Other" include state insurance programs such as accident, sickness, and disability benefit systems. "Assets" are cash and investment holdings of the state employee-retirement systems. The estimated coefficients for Unemployment Insurance funds and Pension and Other funds do not exactly add up to those for State Insurance Trust Funds reported in Table 8 due to differencing. Time-fixed effects not included. Assets and Pension Liabilities data are courtesy of Robert Inman and Stephen Mark. Sample period: 1978-1992 for Assets and Pension Liabilities, 1978-1994 for other data. 
Table 10: The Effect of Balanced-Budget Rules on the Cyclical Patterns of Budget Surpluses

\begin{tabular}{|c|c|c|c|c|c|}
\hline \multirow{2}{*}{\multicolumn{2}{|c|}{ Stringency of Rule: }} & \multicolumn{2}{|c|}{ Total } & \multicolumn{2}{|c|}{ General } \\
\hline & & Low $^{1}$ & $\operatorname{High}^{1}$ & Low $^{1}$ & $\operatorname{High}^{1}$ \\
\hline \multirow[t]{4}{*}{ State } & $k=1$ & $\begin{array}{c}4.23 \\
(5.56)\end{array}$ & $\begin{array}{c}2.62 \\
(6.41)\end{array}$ & $\begin{array}{c}3.13 \\
(6.28)\end{array}$ & $\begin{array}{c}1.98 \\
(6.61)\end{array}$ \\
\hline & P-value: & \multicolumn{2}{|c|}{0.06} & \multicolumn{2}{|c|}{0.05} \\
\hline & $k=3$ & $\begin{array}{c}8.94 \\
(8.25)\end{array}$ & $\begin{array}{c}8.49 \\
(12.47)\end{array}$ & $\begin{array}{c}4.92 \\
(7.13)\end{array}$ & $\begin{array}{c}4.08 \\
(8.38)\end{array}$ \\
\hline & P-value: & & 72 & & \\
\hline \multirow[t]{4}{*}{ Local } & $k=1$ & $\begin{array}{c}1.01 \\
(2.85)\end{array}$ & $\begin{array}{c}0.87 \\
(3.70)\end{array}$ & $\begin{array}{c}0.85 \\
(2.59)\end{array}$ & $\begin{array}{c}0.71 \\
(3.68)\end{array}$ \\
\hline & P-value: & \multicolumn{2}{|c|}{0.73} & \multicolumn{2}{|c|}{0.71} \\
\hline & $k=3$ & $\begin{array}{c}2.81 \\
(8.86)\end{array}$ & $\begin{array}{c}2.14 \\
(4.80)\end{array}$ & $\begin{array}{c}1.75 \\
(3.62)\end{array}$ & $\begin{array}{c}1.27 \\
(3.22)\end{array}$ \\
\hline & P-value: & \multicolumn{2}{|c|}{0.22} & \multicolumn{2}{|c|}{0.44} \\
\hline
\end{tabular}

Notes. ${ }^{1}$ Coefficients $\hat{\beta}_{L}$ and $\hat{\beta}_{H}$, respectively, from the regression $s_{i t}=\alpha_{i}+\beta_{L} \mathrm{D}_{i}^{L} \Delta \mathrm{GSP}_{i t}+$ $\beta_{H}\left(1-\mathrm{D}_{i}^{L}\right) \Delta \mathrm{GSP}_{i t}+\epsilon_{i t}$, where $s$ is the total surplus, GSP is gross state product, and $\mathrm{D}_{i}^{L}$ is a dummy variable which is 1 if state $i$ 's balanced budget rules are less stringent and 0 otherwise.

The " $k=3$ " rows report the $\hat{\beta}$-coefficients from a regression of $s_{i t}+s_{i, t-1}+s_{i, t-2}$ on $\operatorname{GSP}_{i t}-\operatorname{GSP}_{i, t-3}$ interacted with the dummy-variables, using non-overlapping data, allowing for cross-sectional fixed effects. Estimates are scaled by 100 to reflect the response of the corresponding budget surplus to a $\$ 100$ increase in per capita gross state product.

Real per capita 1983 dollars. t-statistics in parentheses. P-values are for the null hypothesis that there is no difference in the point estimates across the low and high stringency groups. Index of balanced-budget stringency is from ACIR (1987), ranging from 0 (least stringent) to 10 (most stringent). Cutoff at index $=7$, yielding groups of size 13 and 35 . Total Surplus includes revenue and expenditure of utilities, liquor stores, and insurance trust funds, while General Surplus does not. Sample period: 1978-1994. 
Table 11: The Effect of Historical Long-Term Debt Levels on the Cyclical Patterns of State Government Budget Surpluses

\begin{tabular}{|c|c|c|c|c|}
\hline \multirow[b]{2}{*}{ Level of Long-Term Debt: } & \multicolumn{2}{|c|}{$\begin{array}{c}\text { Total } \\
\text { Surplus }\end{array}$} & \multicolumn{2}{|c|}{$\begin{array}{l}\text { General } \\
\text { Surplus }\end{array}$} \\
\hline & Low & High & Low & High \\
\hline$k=1$ & $\begin{array}{c}2.39 \\
(5.21)\end{array}$ & $\begin{array}{c}3.95 \\
(6.76)\end{array}$ & $\begin{array}{c}1.68 \\
(5.11)\end{array}$ & $\begin{array}{c}3.34 \\
(8.07)\end{array}$ \\
\hline P-value: & \multicolumn{2}{|c|}{0.04} & \multicolumn{2}{|c|}{0.00} \\
\hline$k=3$ & $\begin{array}{c}8.04 \\
(10.86)\end{array}$ & $\begin{array}{c}9.41 \\
(10.43)\end{array}$ & $\begin{array}{c}3.19 \\
(6.39)\end{array}$ & $\begin{array}{c}5.90 \\
(9.79)\end{array}$ \\
\hline P-value: & \multicolumn{2}{|c|}{0.24} & \multicolumn{2}{|c|}{0.00} \\
\hline
\end{tabular}

Notes. The regressions are similar to those reported in Table 10.

Real per capita 1983 dollars. t-statistics in parentheses. P-values are for the null hypothesis that there is no difference in the point estimates across the two groups. States are classified according to 1978 net per capita state government debt levels. Groups are of equal size. Total Surplus includes revenue and expenditure of utilities, liquor stores, and insurance trusts funds, while General Surplus does not. Sample period: 1978-1994. 
Table 12: Disentangling the Effect of Balanced Budget Rules and of Historical Debt Levels

\begin{tabular}{|c|c|c|c|c|}
\hline \multicolumn{5}{|c|}{ Regression: $\hat{\beta}_{i}=\alpha_{0}+\alpha_{1} \log \operatorname{GSP}_{i}+\alpha_{2} \log \operatorname{LTDS}_{i, t_{0}}+\alpha_{3} \operatorname{INDEX}_{i}+\varepsilon_{i}$} \\
\hline & $\alpha_{0}$ & $\alpha_{1}$ & $\alpha_{2}$ & $\alpha_{3}$ \\
\hline$k=1$ & $\begin{array}{c}-4.07 \\
(-0.72)\end{array}$ & $\begin{array}{c}-1.28 \\
(-0.27)\end{array}$ & $\begin{array}{c}1.41 \\
(2.71)\end{array}$ & $\begin{array}{c}-0.28 \\
(-1.02)\end{array}$ \\
\hline$k=3$ & $\begin{array}{c}-3.68 \\
(-0.43)\end{array}$ & $\begin{array}{c}-5.66 \\
(-0.80)\end{array}$ & $\begin{array}{c}1.39 \\
(1.76)\end{array}$ & $\begin{array}{c}-0.03 \\
(-0.07)\end{array}$ \\
\hline
\end{tabular}

Notes. We first estimate the cyclical response of state $i$ 's government budget surplus using the time-series regression coefficient $\hat{\beta}_{i}=100 * \operatorname{Cov}\left(\mathrm{s}_{i t}, \Delta \operatorname{GSP}_{i t}\right) / \operatorname{Var} \Delta \operatorname{GSP}_{i t}(" k=1$ ") and the coefficient $\hat{\beta}_{i}=100 * \operatorname{Cov}\left(\mathrm{S}_{i t}+\mathrm{S}_{i, t-1}+\mathrm{S}_{i, t-2}, \operatorname{GSP}_{i t}-\operatorname{GSP}_{i, t-3}\right) / \operatorname{Var}\left(\operatorname{GSP}_{i t}-\operatorname{GSP}_{i, t-3}\right)$ ( " $k=3$ "). Then we perform the above cross-sectional multivariate regression where GSP $i$ is the average of $\operatorname{GSP}_{i t}$ over the sample years, $\operatorname{LTDS}_{i, t_{0}}$ is the level of state government net long-term debt in 1978 (the first year of the sample), and INDEx $i$ is the balanced budget stringency index. By including both the debt level and the stringency index we can evaluate the marginal impact of each when the other is controlled for.

Real per capita 1983 dollars. t-statistics in parentheses. Sample period: 1978-1994. 
Table 13: The Effect of the Type of Taxes More Heavily Used on the Cyclical Patterns of the Total Surplus

\begin{tabular}{|c|c|c|c|c|c|c|c|c|}
\hline \multirow{3}{*}{$\begin{array}{l}\text { Type of Tax: } \\
\text { Share in Total } \\
\text { Tax Revenue: }\end{array}$} & \multicolumn{6}{|c|}{ State } & \multicolumn{2}{|c|}{ Local } \\
\hline & \multicolumn{2}{|c|}{ Personal } & \multicolumn{2}{|c|}{ Sales } & \multicolumn{2}{|c|}{ Severance } & \multicolumn{2}{|c|}{ Property } \\
\hline & Low & High & Low & High & Low & High & Low & High \\
\hline Average Share: & $12 \%$ & $34 \%$ & $21 \%$ & $41 \%$ & $0 \%$ & $6 \%$ & $71 \%$ & $95 \%$ \\
\hline$k=1$ & $\begin{array}{c}2.55 \\
(5.03)\end{array}$ & $\begin{array}{c}3.44 \\
(6.69)\end{array}$ & $\begin{array}{c}4.04 \\
(7.33)\end{array}$ & $\begin{array}{c}2.19 \\
(4.36)\end{array}$ & $\begin{array}{c}3.81 \\
(7.41)\end{array}$ & $\begin{array}{c}2.20 \\
(4.36)\end{array}$ & $\begin{array}{c}0.86 \\
(2.92)\end{array}$ & $\begin{array}{c}0.97 \\
(3.68)\end{array}$ \\
\hline P-value: & \multicolumn{2}{|c|}{0.22} & \multicolumn{2}{|c|}{0.01} & \multicolumn{2}{|c|}{0.03} & \multicolumn{2}{|c|}{0.80} \\
\hline$k=3$ & $\begin{array}{c}8.63 \\
(11.69)\end{array}$ & $\begin{array}{c}8.61 \\
(9.33)\end{array}$ & $\begin{array}{c}9.65 \\
(10.04)\end{array}$ & $\begin{array}{c}8.02 \\
(11.29)\end{array}$ & $\begin{array}{c}9.23 \\
(11.29)\end{array}$ & $\begin{array}{c}7.99 \\
(9.88)\end{array}$ & $\begin{array}{c}2.59 \\
(4.83)\end{array}$ & $\begin{array}{c}2.56 \\
(8.39)\end{array}$ \\
\hline P-value: & \multicolumn{2}{|c|}{0.99} & \multicolumn{2}{|c|}{0.17} & \multicolumn{2}{|c|}{0.28} & \multicolumn{2}{|c|}{0.96} \\
\hline
\end{tabular}

Notes. The regressions are similar to those reported in Table 10.

Real per capita 1983 dollars. t-statistics in parentheses. P-values are for the null hypothesis that there is no difference across the two groups. Groups are of equal size, and are classified according to 1978 tax shares. "Personal": Personal Income Taxes. "Sales": General Sales and Gross Receipts Taxes. The share of personal, sales, and severance taxes are calculated as shares of total state government tax revenue. The share of property taxes is calculated as the share in total local government tax revenue. Total Surplus includes revenue and expenditure of utilities, liquor stores, and insurance trust funds. "Average Share" is the average (over the states in the sub-group) fraction of total (state or local) tax revenue raised by the tax source considered. Sample period: 1978-1994. 
Table 14: Cyclical Patterns of the Total Surplus of State Government Budgets in Election Years

\begin{tabular}{|c|c|c|c|c|c|}
\hline \multirow[b]{2}{*}{ Election Year: } & \multirow{2}{*}{$\begin{array}{c}\text { All Shocks } \\
\text { Yes }\end{array}$} & \multicolumn{2}{|c|}{ Positive Shocks } & \multicolumn{2}{|c|}{ Negative Shocks } \\
\hline & & Yes & No & Yes & No \\
\hline Estimate: & $\alpha_{0}$ & $\alpha_{1}$ & $\alpha_{2}$ & $\alpha_{3}$ & $\alpha_{4}$ \\
\hline$k=1$ & $\begin{array}{l}-10.43 \\
(-0.91)\end{array}$ & $\begin{array}{c}-0.40 \\
(-0.28)\end{array}$ & $\begin{array}{c}3.80 \\
(5.91)\end{array}$ & $\begin{array}{c}2.89 \\
(2.73)\end{array}$ & $\begin{array}{c}3.00 \\
(5.63)\end{array}$ \\
\hline$k=1$ & - & -1.04 & 3.80 & 3.39 & 3.00 \\
\hline
\end{tabular}

Notes. The first row displays results of the regression $s_{i t}=\alpha_{i}+\alpha_{0} \mathrm{D}_{i t}^{E}+\alpha_{1} \mathrm{D}_{i t}^{E} \Delta \operatorname{GSP}_{i t}^{+}+\alpha_{2}(1-$ $\left.\mathrm{D}_{i t}^{E}\right) \Delta \operatorname{GSP}_{i t}^{+}+\alpha_{3} \mathrm{D}_{i t}^{E} \Delta \operatorname{GSP}_{i t}^{-}+\alpha_{4}\left(1-\mathrm{D}_{i t}^{E}\right) \Delta \operatorname{GSP}_{i t}^{-}$, where $s_{i t}$ is the total budget surplus, $\mathrm{D}_{i t}^{E}$ is a dummy variable which takes the value 1 if year $t$ is an election year in state $i$ (0 otherwise), $\Delta \mathrm{GSP}_{i t}^{+}$is equal to $\Delta \mathrm{GSP}_{i t}$ if $\Delta \mathrm{GSP}_{i t}$ is above its own average (over time for state $i$ ), and $\Delta \mathrm{GSP}_{i t}^{-}$, correspondingly, for years of below average $\Delta \mathrm{GSP}_{i t}$. The second row is estimated with $\alpha_{0}=0$. Estimates are scaled by 100 to reflect the response of the corresponding budget surplus to a $\$ 100$ increase in per capita gross state product. Total Surplus refers to the total surplus of the state government budget including utilities, insurance trusts, and liquor stores.

Real per capita 1983 dollars. t-statistics in parentheses. Sample period: 1978-1994. 
Table 15: The Effect of Ideology

on the Cyclical Patterns of the Budget Surplus

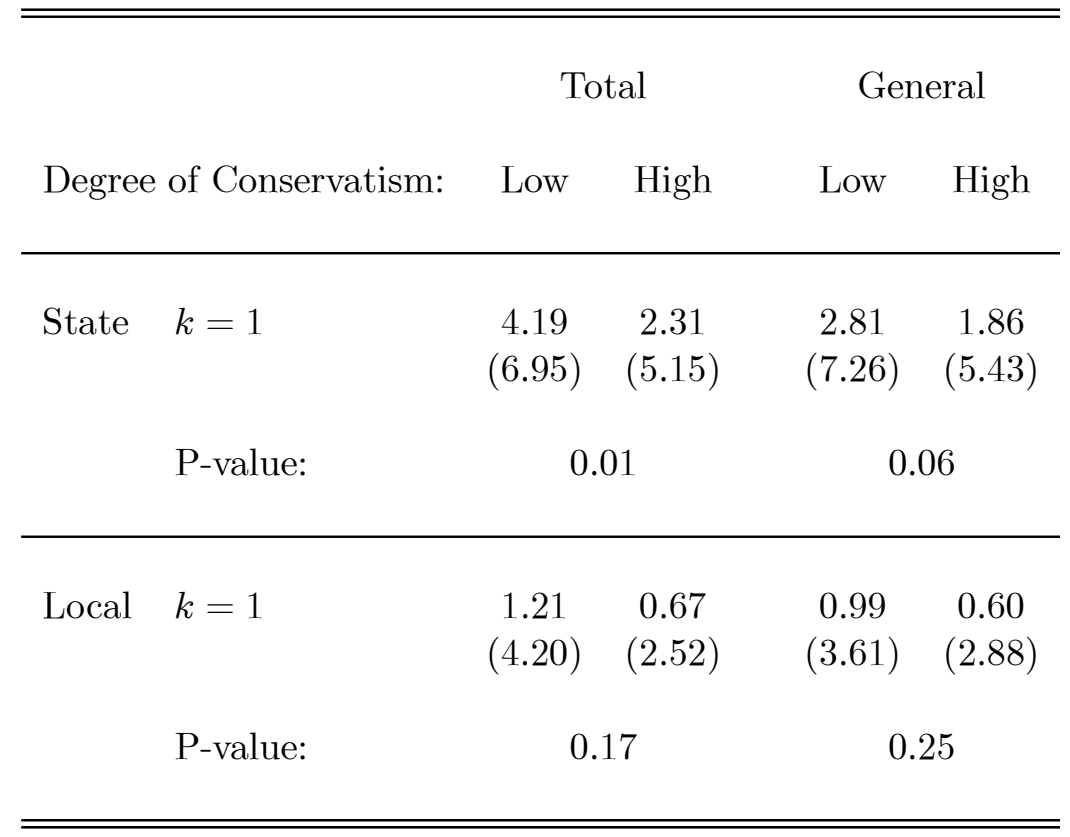

Notes. The regressions are similar to those reported in Table 10.

Real per capita 1983 dollars. t-statistics in parentheses. P-values are for the null hypothesis that there is no difference across the two groups. Groups are of equal size. Degree of Conservatism is measured as percent conservatives minus percent liberals as self-reported. The index ranges across states from 0 to 28 . The average values of the index in low and high groups are 8 and 20, respectively. Sample period: 1978-1994. 
Table 16: Income Smoothing through State and Local Government Fiscal Policy

\begin{tabular}{ccc}
\hline \hline Regression: $\Delta \log \left(\mathrm{DPI}_{i t}+\mathrm{S}_{i t}\right)-\Delta \log \mathrm{DPI}_{i t}=\nu_{t}+\beta \Delta \log \operatorname{GSP}_{i t}+u_{i t}$. \\
& $k=1$ & $k=3$ \\
& & \\
State & 3.01 & 2.94 \\
& $(3.74)$ & $(4.00)$ \\
& & \\
Local & 0.73 & 0.78 \\
& $(1.66)$ & $(2.10)$ \\
\hline \hline
\end{tabular}

Notes. Percentage of idiosyncratic shocks to gross state product absorbed by the state or local government surplus. In the " $\mathrm{k}=3$ " column, the data are differenced using nonoverlapping 3-year intervals. $\nu_{t}$ denotes time-fixed effects. DPI $i t$ is state $i$ 's real disposable income in period $t$ and $\mathrm{s}_{i t}$ is the total surplus of state $i$ 's state government (for the row "State") or local governments (for the row "Local") measured in real per capita dollars. t-statistics in parentheses. Sample period: 1978-1994. 


\section{Effect on State Budget Components of a 100 Dollar Permanent Increase in GSP}

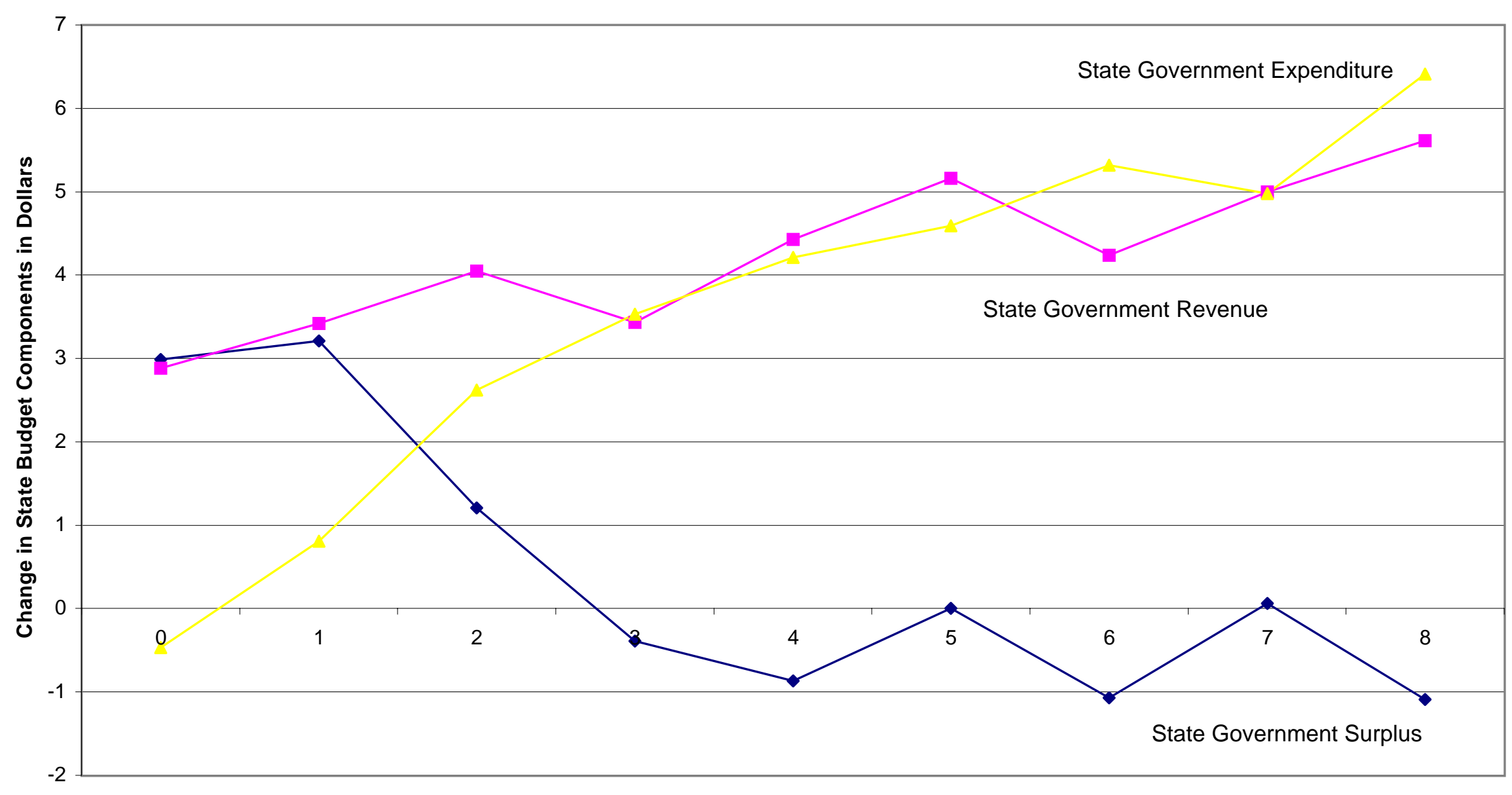

Years

Fig. 1: The graph shows the effect (in real per capita dollars) on state government total revenue, expenditure and surplus from a one time permanent change of 100 dollars in real per capita GSP. The graph is based on regressions of budget components on current and lagged GSP. (See equations (6), (7), and (8)). Sample: 1978 - 1994. 